Slev, V.N., Mistiaen, P., Pasman, H.R.W., Verdonck-de Leeuw, I.M., Uden-Kraan, C.F. van, Francke, A.L. Effects of eHealth for patients and informal caregivers confronted with cancer: a meta-review. International Journal of Medical Informatics: 2016, 87, 54-67

\begin{tabular}{|l|l|}
\hline $\begin{array}{l}\text { Postprint } \\
\text { Version }\end{array}$ & 1.0 \\
\hline Journal website & http://www.ijmijournal.com/article/S1386-5056(15)30080-0/abstract \\
\hline Pubmed link & $\underline{\text { http://www.ncbi.nlm.nih.gov/pubmed/26806712 }}$ \\
\hline DOI & $10.1016 /$ j.ijmedinf.2015.12.013 \\
\hline
\end{tabular}

This is a NIVEL certified Post Print, more info at http://www.nivel.eu

\title{
Effects of eHealth for patients and informal caregivers confronted with cancer: A meta-review
}

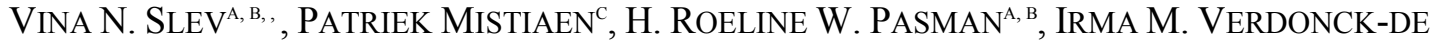 \\ LEEUW $^{\mathrm{D}, \mathrm{E}}$, CORNELIA F. VAN UDEN-KRAAN ${ }^{\mathrm{E}}$, ANNEKE L. FRANCKE ${ }^{\mathrm{A}, \mathrm{B}, \mathrm{C}}$ \\ a VU University Medical Center, Department of Public and Occupational Health, The EMGO \\ Institute for Health and Care Research, Amsterdam, Netherlands \\ b Expertise Center for Palliative Care, Amsterdam, Netherlands \\ c NIVEL, Netherlands Institute for Health Services Research Utrecht, Netherlands \\ d VU University Medical Center, Department of Otolaryngology-Head \& Neck Surgery, The \\ EMGO Institute for Health and Care Research, Cancer Center Amsterdam (CCA), \\ Amsterdam, Netherlands \\ e Vrije Universiteit Amsterdam, Department of Clinical Psychology, The EMGO Institute for \\ Health and Care Research, Cancer Center Amsterdam (CCA), Amsterdam, Netherlands
}

\section{Highlights}

- Evidence for effects on perceived support, knowledge, and information competence.

- Indications of evidence for, among more, health status, and patient involvement

- Inconsistent findings for, among more, psychological outcomes and quality of life.

- No focus on informal caregivers, various disease stages, and specific tumour types.

\begin{abstract}
Background: eHealth can be defined as information provision about illness or health care and/or support for patients and/or informal caregivers, using the computer or related technologies. eHealth interventions are increasingly being used in cancer care, e.g. to support patients and informal caregivers in managing symptoms and problems in daily life.

Objectives: To synthesize evidence from systematic reviews on the effects of eHealth for cancer patients or their informal caregivers.

Materials and Methods: A systematic meta-review, in the sense of a systematic review of reviews, was conducted. Searches were performed in PubMed, Embase, CINAHL, PsycINFO, and the Cochrane Library. All steps in the review process were either performed by two reviewers independently or checked by a second reviewer. Disagreements were resolved by consensus.

Results: Ten systematic reviews were included. All reviews focused on the effects of eHealth for patients and none on effects for informal caregivers. Except for one review of high methodological quality, all reviews were of
\end{abstract}


Slev, V.N., Mistiaen, P., Pasman, H.R.W., Verdonck-de Leeuw, I.M., Uden-Kraan, C.F. van, Francke, A.L. Effects of eHealth for patients and informal caregivers confronted with cancer: a meta-review. International Journal of Medical Informatics: 2016, 87, 54-67

moderate methodological quality. Evidence was found for effects on perceived support, knowledge levels, and information competence of cancer patients. Indications of evidence were found for health status and healthcare participation. Findings were inconsistent for outcomes related to decisionmaking, psychological wellbeing, depression and anxiety, and quality of life. No evidence was found for effects on physical and functional wellbeing.

Conclusion: There is evidence for positive effects of eHealth on perceived support, knowledge, and information competence of cancer patients. For effects on other outcomes in cancer patients, findings are mainly inconsistent or lacking. This meta-review did not find relevant reviews focusing on or including the effects of eHealth on informal caregivers, which seems a rather unexplored area.

\section{INTRODUCTION}

Cancer and its treatment make a great demand on patients as well as on informal caregivers. Cancer patients often suffer from problems and symptoms such as pain, fatigue, depression, anxiety, and hopelessness [1]. In addition, their informal caregivers often experience a high care burden, psychological problems, and a decrease in social activities [2]. Professional support can help them in dealing with these symptoms and problems. However, given that many people prefer to keep control over their own life and in view of increasing healthcare costs, it is not selfevident that all support should be given in face-to-face contacts between professionals and care recipients. EHealth may complement or replace traditional professional support to some extent [3] and [4]. We define eHealth as the provision of information about illness or health care and/or support for patients and/or informal caregivers using computers or related technologies. Our definition is inspired by Eysenbach's well-known statement describing eHealth as “....an emerging field in the intersection of medical informatics, public health and business, referring to health services and information delivered or enhanced through the internet and related technologies" [5].

Nowadays, various computer-based and internet-based eHealth interventions are available for patients and informal caregivers confronted with cancer. These interventions provide information about cancer and its treatment (e.g. www.oncolink.org), support in decision-making (e.g. www.prostaatkankerkeuzehulp.nl), support in self-management, (e.g. www.oncokompas.nl), support for physical and emotional problems (e.g. www.helpforcancercaregivers.com), and peer support (e.g. www.cancerstories.info). Given the growing importance of eHealth in modern health care, it is relevant to see what evidence already exists regarding the effects of eHealth in people confronted with cancer. Since several systematic reviews had already been published, we performed a meta-review in which we analyzed and synthesized the evidence from existing reviews. In this meta-review we address the following primary question:

1. What evidence can be derived from existing systematic reviews about the effects of eHealth for patients with cancer and/or their informal caregivers? 
Slev, V.N., Mistiaen, P., Pasman, H.R.W., Verdonck-de Leeuw, I.M., Uden-Kraan, C.F. van, Francke, A.L. Effects of eHealth for patients and informal caregivers confronted with cancer: a meta-review. International Journal of Medical Informatics: 2016, 87, 54-67

The secondary question is:

2. What specific types of eHealth interventions for patients with specific types of cancer and/or their informal caregivers are addressed in the relevant systematic reviews?

\section{MATERIAL AND METHODS}

\subsection{Design}

We conducted a meta-review, i.e. a systematic review of reviews. This review type is suitable for describing the quality, discerning the heterogeneity, and identifying lacunas in the current evidence base, since it synthesizes evidence from relevant previous systematic reviews [6].

\subsection{Eligibility criteria}

References were eligible for inclusion if they concerned a literature review that satisfies all of the following four criteria, namely if it:

1) reports on the effects of eHealth. As stated before, we define eHealth as the provision of information about illness or health care and/or support for patients or informal caregivers using computers or related technologies;

2) concerns the effects on adult patients diagnosed with cancer and/or their informal caregivers. Reviews that also include studies among non-cancer groups were only eligible for inclusion if they reported the effects on cancer patients separately;

3 ) is a systematic review. We considered a review 'systematic' if the following criteria were satisfied: (a) search terms are presented; (b) searches are done in Pubmed/Medline or Cancerlit and at least one other international literature database;

4) has an overall methodological score of $\geq 3$ (see Section '2.5 Quality assessment').

\subsection{Search methods and terms}

First, we developed a search strategy for PubMed, which is available as supplementary material. Subsequently, we adapted the strategy for searches in Embase, CINAHL, PsycINFO, and The Cochrane Library. For the development and adaption of the search strategies, databases' thesaurus terms for eHealth, cancer, systematic review and meta-analysis or specific 'systematic review filters' were used, as well as free text words describing eHealth. The searches were performed on March 6th 2014.

\subsection{Review selection}

The review selection process consisted of three phases:

1) Screening of titles and abstracts. First, VNS and HRP independently screened the titles and available abstracts of a random selection of $10 \%$ of the references identified. The interrater agreement between the two reviewers about the final inclusion and exclusion was $100 \%$. The interrater agreement about whether the three separate inclusion criteria were met was $99.59 \%$ on average. Next, the remaining $90 \%$ of the references were divided among VNS and HRP, who each screened the titles and available abstracts of 3600 references. Finally, they discussed the list of 
Slev, V.N., Mistiaen, P., Pasman, H.R.W., Verdonck-de Leeuw, I.M., Uden-Kraan, C.F. van, Francke, A.L. Effects of eHealth for patients and informal caregivers confronted with cancer: a meta-review. International Journal of Medical Informatics: 2016, 87, 54-67

references eligible for full text screening as well as references where it was not very clear whether they should be included or excluded.

2) The full texts of all references remaining after the first selection phase were then screened by VNS and ALF independently, using the first three inclusion criteria. The interrater agreement between the two reviewers was high: In $84 \%$ of the references they agreed about the final inclusion and exclusion. Discrepancies were discussed until consensus was reached.

3) Subsequently VNS and ALF independently assessed the methodological quality of the references remaining after the second selection phase (see Section '2.5 Quality assessment'). In accordance with the fourth criterion concerning the methodological quality, only studies with a methodological score of 3 or more were finally included. Also in this phase, discrepancies were discussed and resolved by consensus.

\subsection{Quality assessment}

After review selection, the methodological quality of the systematic reviews was assessed using the Quality Assessment Checklist for Reviews [7] and [8]. This checklist is one of the few for which the psychometric properties have been documented [9], and it has been used in other meta-reviews [10] and [11]. The overall scores on this checklist range from "extensive flaws" (score 1 or 2 ), to "major flaws" (score 3 or 4), "minor flaws" (score 5 or 6 ) and "minimal flaws" (score 7). We calculated the average overall score when the overall scores of the VNS and ALF differed by 1 point. Differences of 2 or more points were resolved by consensus. For the best evidence synthesis (see Section '2.7 Data synthesis'), we classified the scores into three quality categories: "high quality" (score 5-7), "moderate quality" (score 3-4.5) and "low quality" (score 1-2.5).

\section{[TABLE 1]}

\subsection{Data extraction}

A pre-defined data extraction form-encompassing such items as the review aim, cancer type, types of eHealth, and reported outcomes - was used to extract data from the reviews. VNS performed the data extraction and IMVdL or CFU independently cross-checked the extracted information. We only extracted data concerning the effects of eHealth on cancer patients and/or informal caregivers, although some of the reviews had a broader focus, e.g. chronic conditions (including cancer).

\subsection{Data synthesis}

We categorized outcomes into categories including "psychological wellbeing", "depression", "anxiety", "knowledge and information", and "decision-making". The categorization was based on the types of outcomes reported in the reviews.

Pooling of results was impossible because of the large variety of methods used and eHealth interventions studied, and the lack of numeric results in the reviews. We did, however, indicate the level of evidence regarding the effects of eHealth on a specific outcome category, using the criteria displayed in Box 1. These criteria were inspired by the principles of best evidence synthesis in systematic reviews, as developed by Steultjens et al. [12]. However, we had to adjust the criteria of Steultjens et al. [12] since we conducted a systematic meta-review of reviews rather than a traditional systematic review of RCTs. Adjustments concerned redefining the levels of evidence 
Slev, V.N., Mistiaen, P., Pasman, H.R.W., Verdonck-de Leeuw, I.M., Uden-Kraan, C.F. van, Francke, A.L. Effects of eHealth for patients and informal caregivers confronted with cancer: a meta-review. International Journal of Medical Informatics: 2016, 87, 54-67

and corresponding criteria by taking into consideration the methodological quality of the included reviews rather than of the methodological quality of separate RCTs.

\section{RESULTS}

\subsection{Results of review selection and quality assessment}

Through the searches, we identified 8157 unique potentially relevant references (Fig. $1)$.

After examining the titles and available abstracts, 50 references remained for screening based on their full text versions. Thirteen review papers turned out to be eligible for inclusion, and were assessed on their methodological quality, subsequently.

Only one review [13] received a high quality rating, namely 5 points on the checklist used, indicating only minor flaws (Table 1).

Nine reviews [14], [15], [16], [17], [18], [19], [20], [21] and [22] were judged as likely to have major flaws (score range: 3-4.5). In general, these reviews scored best on items concerning the description and comprehensiveness of searches, and use of explicit inclusion and exclusion criteria. However, most reviews scored poorly on items referring to an independent reference selection and screening and items referring to a methodological appraisal or data synthesis.

Three reviews [23], [24] and [25] had a very low quality rating of 1 or 2, and were excluded (in accordance with Exclusion Criterion no. 4 described in Section '2.2 Eligibility criteria') in the end. Consequently, ten reviews remained for inclusion in this meta-review.

\subsection{General and methodological characteristics of the ten reviews and their underlying studies}

Table S1 provides an overview of the ten reviews' main general and methodological characteristics, such as the eligibility criteria used. Table $\mathrm{S} 1$ is available as a supplementary material. Only one review [14] explicitly mentioned family caregivers as well as patients in the inclusion criteria. All other reviews explicitly excluded studies about informal caregivers or did not make any statement regarding informal caregivers. Eight reviews exclusively included studies focusing on cancer patients (type unspecified) and two specifically included studies in breast cancer or prostate cancer populations [20] and [21]. Most of the reviews did not restrict their eligibility criteria to patients in a certain disease stage or clinical stage. Two reviews specified outcomes in their eligibility criteria, such as distress, emotional wellbeing, and depressive symptoms [13] and [15].

Table S1 also includes the main characteristics of the reviews' underlying studies. These studies were often RCTs or quasi-experimental studies among patients with breast cancer, prostate cancer, or colorectal cancer, or mixed groups of cancer patients. Only one underlying study also concentrated on patients' partners. There was also great variety regarding the disease stage or clinical stage; studies concerned newly diagnosed patients, patients under treatment, or post-surgery patients. There appeared to be some overlap in the underlying studies included in the ten reviews, since reviews often included the same underlying studies, such as studies of the eHealth intervention known as the Comprehensive Health Enhancement Support System for breast cancer patients (CHESS) [26], [27], [28] and [29]. 
Slev, V.N., Mistiaen, P., Pasman, H.R.W., Verdonck-de Leeuw, I.M., Uden-Kraan, C.F. van, Francke, A.L. Effects of eHealth for patients and informal caregivers confronted with cancer: a meta-review. International Journal of Medical Informatics: 2016, 87, 54-67

\section{[FIGURE 1]}

\subsection{Characteristics of the eHealth interventions}

Most of the reviews did not clearly define what type of interventions they were interested in. Only Ryhanen et al. [20] gave a definition of the eHealth interventions they focused on, namely "Internet-based patient education as the use of the World Wide Web or with modem connections to a central server for communication for patient education" [20].

All reviews, except for one, included studies concerning internet-based and/or computer-based interventions (Table 2).Bender et al. [14] were the only ones who focused solely on smartphone applications.

Most eHealth interventions studied were multi-component with a mixture of information and support. In some cases, coping skills training [13], [14], [15] and [20] or monitoring and tracking features [14], [19] and [21] were also part of the content. Different forms of support were available like emotional and/or psychosocial support [15], [18], [21] and [22], reminders for appointments or medication [14], and psycho-educational strategies [21]. Support was provided through, for example, a 'chat functionality' with healthcare professionals or by other cancer patients (peer support) [13], [14], [15], [16], [17], [18] and [20]. The abovementioned CHESS eHealth intervention is also multi-component and involves components like information, discussion groups, and treatment decision aids. Only Griffiths et al. [15] separately analyzed and compared single-component eHealth interventions versus multi-component interventions. Single-component eHealth interventions concerned internet support groups, for example, where participants could exchange personal stories.

\section{[TABLE 2]}

\subsection{Effects of the eHealth interventions}

All reviews except one [14] found studies concerning the effects of eHealth interventions. Bender et al. [14] did not find any study meeting their eligibility criteria, most likely due to their narrow focus on smartphone applications available in Canadian and French online application stores. The results of the nine remaining reviews are presented in Table S2 which is available as supplementary material. The reviews studied a variety of outcomes and were based on underlying studies using different, mostly multiple, points in time, varying from pre-test, post-test, and follow-up after nine months, to baseline, six weeks, and 12 weeks.

Since many different outcomes were reported, we consider only those outcome categories that are discussed in a majority of the reviews. The level of evidence for each outcome category is summarized in Table 3.

\subsubsection{Effects on knowledge and information competence}

Evidence exists for positive effects of eHealth interventions on knowledge and information competence (the ability to acquire information as well as to use the acquired information) [16], [18], [20] and [21].

\section{[BOX 1]}

Gysels and Higginson [16], who studied the effects of interactive multimedia programs, elaborated on a study describing increased knowledge levels about breast cancer and improvements in information competence in women with breast cancer 
Slev, V.N., Mistiaen, P., Pasman, H.R.W., Verdonck-de Leeuw, I.M., Uden-Kraan, C.F. van, Francke, A.L. Effects of eHealth for patients and informal caregivers confronted with cancer: a meta-review. International Journal of Medical Informatics: 2016, 87, 54-67

two months and five months after attending an internet support group, and on women who are non-Caucasian, uninsured or less educated. These findings appear to be supported by Ryhanen et al. [20]. Comparable results were yielded for prostate cancer patients. Hong et al. [18] found some evidence for improvements in information competence, information seeking, and information exchange in a patient population with various types of cancer.

\subsubsection{Effects on perceived support}

Evidence is also found for positive effects of eHealth interventions on perceived support [16], [17], [18], [19], [20], [21] and [22].

Table S2 shows that three reviews [17], [18] and [22] described positive effects on the provision of social support and one review [19] on the reduction in perceived needs for support. Two reviews specifically mentioned eHealth interventions positively influencing the provision of social support for breast cancer patients [16] and [20]. Salonen et al. [21] reported some improvement in informational support to prostate cancer patients and satisfaction with that support. Similar results for breast cancer patients were found by Hoey et al. [17].

3.4.3. Effects on decision-making

Findings concerning the effects of eHealth interventions on decision-making are inconsistent [16], [20], [21] and [22].

While two reviews [20] and [22] solely found positive effects, Gysels and Higginson [16] found mixed results for the effects of interactive multimedia technologies on decision-making by breast cancer patients regarding treatment, namely studies describing positive effects as well as studies describing no effects on breast cancer patients' satisfaction with decision making concerning treatment. Gysels and Higginson explained these mixed findings as a result of the differences between the studied eHealth interventions. Additionally, Salonen et al. [21] described the results of internet and computer-based programs for prostate cancer patients and found that these programs positively influenced not only levels of decision control, and patient involvement in decision-making but also decisional conflict.

\subsubsection{Effects on healthcare participation and patient involvement}

Indications of evidence exist for positive effects of eHealth interventions on healthcare participation and patient involvement in care [16], [17], [18], [20] and [22].

Results varied from positive effects to no effects, but mainly involved positive effects. Table S2 shows that positive effects on healthcare participation were experienced by breast cancer patients after two months of using an internet-based program [16], [17], [18] and [20] and by women with breast cancer who are nonCaucasian, uninsured, or less educated [16]. The effect on healthcare participation after two months, however, seemed to dissolve after five months [16]. There also appeared to be no effect on patient involvement during consultations for choosing breast cancer treatment [16]. Ventura et al. [22] described mixed results on healthcare participation but mostly positive ones.

\section{[TABLE 3]}

\subsubsection{Effects on depression and anxiety}

Inconsistent findings were yielded regarding depression [15], [16], [17], [18], [19], [20] and [21] and anxiety [16], [17], [19] and [20]. 
Slev, V.N., Mistiaen, P., Pasman, H.R.W., Verdonck-de Leeuw, I.M., Uden-Kraan, C.F. van, Francke, A.L. Effects of eHealth for patients and informal caregivers confronted with cancer: a meta-review. International Journal of Medical Informatics: 2016, 87, 54-67

With regard to the effects on depression, Griffiths et al. [15], Hoey et al. [17], and Hong et al. [18] found positive effects from internet support groups and online cancer support and resources on symptoms of depression in breast cancer patients and survivors. These findings are likely to be strengthened by the result that showed internet support groups to be more successful for patients with breast cancer than for patients with other (non-cancer) diagnoses [15]. However, two reviews [16] and [18] also reported that the aforementioned finding is likely not to apply to recently diagnosed breast cancer patients [18] and women with early stage breast cancer [16]. Additionally, Griffiths et al. [15] reported no effects of multi-component internet support groups on breast cancer patients and head and neck cancer patients. With respect to prostate cancer patients, Salonen et al. [21] found positive results for internet and computer-based programs in reducing depression. Electronic symptom reporting in the context of consultation support appeared to reduce depression as well [19].

Four reviews reported varying results concerning effects on anxiety [16], [17], [19] and [20]. Ryhanen et al. [20] found no effect of internet and computer-based programs on anxiety among breast cancer patients. Gysels and Higginson [16] seem to contradict this result by reporting that the use of interactive multimedia programs during the discussion of diagnosis and treatment helped reduce anxiety among breast cancer patients. Internet peer support programs [17] and electronic symptom reporting [19] were also found to reduce anxiety in breast cancer patients and cancer patients in general respectively.

\subsubsection{Effects on psychological wellbeing}

Findings on the effects of eHealth interventions on psychological wellbeing and related outcomes are inconsistent [13], [15], [17], [18], [19] and [21].

Hoey et al. [17] and Hong et al. [18] found mixed effects and no effects respectively of online cancer support (from peers) on emotional wellbeing [17] and [18]. Johansen et al. [19] found underlying studies on electronic symptom reporting that demonstrated a positive impact from providing feedback on emotional wellbeing but they found no effect for electronic symptom reporting in general.

Psychological wellbeing was discussed in four reviews [13], [15], [18] and [21]. Beatty and Lambert [13] and Salonen et al. [21] present contradictory findings for the effects on psychological distress: Beatty and Lambert argue that online interventions had no impact while Salonen et al. see a positive impact.

\subsubsection{Effects on quality of life and health status}

Findings on the effects of eHealth interventions on quality of life are inconsistent [13], [16], [17], [18], [19], [21] and [22].

Some reviews found positive effects [16], [19] and [21], while others did not [13] and [17] or found mixed results [17] and [22]. For instance, Gysels and Higginson [16] found one study describing positive effects of internet support groups specifically for women with breast cancer and who are of color, uninsured, or with less education. Johansen et al. [19] described positive effects of electronic symptom reporting on the health-related quality of life. However, Hong et al. [18] studied online cancer support and found no effects on the health-related quality of life, while these authors did find positive effects on the self-reported quality of life. Ventura et al. [22] discussed comparable mixed results. 
Slev, V.N., Mistiaen, P., Pasman, H.R.W., Verdonck-de Leeuw, I.M., Uden-Kraan, C.F. van, Francke, A.L. Effects of eHealth for patients and informal caregivers confronted with cancer: a meta-review. International Journal of Medical Informatics: 2016, 87, 54-67

The four reviews reporting on outcomes relates to health status presented results that are inconsistent [13], [16], [18] and [22]. Two reviews [13] and [16] found positive effects. However, one review [22] described some studies with positive effects on general health and others with no effects on general health of internet or computerbased programs. Both Ventura et al. [22] and Hong et al. [18] found no effects on the self-rated health status.

\subsubsection{Effects on physical and functional wellbeing}

No evidence is found for effects of eHealth interventions on physical [13], [17] and [18] and functional wellbeing [18].

One review [18] found mixed results concerning physical wellbeing and another [17] found positive effects. Positive effects specifically concerned reductions in patients' reaction to pain. These findings, however, are contradicted by Beatty and Lambert's high quality review [13] that found no effects on physical wellbeing. Functional wellbeing was mentioned in only one review and appeared not to be influenced two months after using an online cancer support program [18].

\section{DISCUSSION}

This meta-review shows that evidence exists for effects of eHealth on cancer patients' knowledge level, and information competence. Patients' knowledge levels increased as well as their ability to acquire information and to use the acquired information [16], [18], [20] and [21]. The use of eHealth also reduced patients' needs for support as it improved provision of support [16], [17], [18], [19], [20], [21] and [22]. Evidence regarding health status [13], [16], [18] and [22], healthcare participation and patient involvement in care is sparse [16], [17], [18], [20] and [22], since we found only indications for effects of eHealth on these outcomes. Although results described in the systematic reviews mainly concerned positive effects [13], [16], [17], [18], [20] and [22], they also reported studies showing no effects on mentioned outcomes. Findings are inconsistent with regard to effects on psychological outcomes (psychological wellbeing [13], [15], [17], [18], [19] and [21], depression [15], [16], [17], [18], [19], [20] and [21], and anxiety [16], [17], [19] and [20]), quality of life [13], [16], [17], [18], [19], [21] and [22], and decision-making about treatment or care [16], [20], [21] and [22]. For example, some systematic reviews described positive effects on patients' satisfaction with their decision about treatment, while other systematic reviews found mixed or no effects in this regard. Besides, evidence is lacking for effects on physical [13], [17] and [18] and functional wellbeing [18]. Remarkably, only one review [14] aimed to consider the effects of eHealth for informal caregivers as well as patients. Since this review did not find any effect studies at all, evidence for the effects of eHealth for informal caregivers could not be obtained. Moreover, of the three reviews that were excluded because of poor methodological quality, two [23] and [24] did not include studies on the effects of eHealth in informal caregivers of cancer patients. Nevertheless, we do have indications that some research into the effects of eHealth on informal caregivers has already been conducted, e.g. Farnham et al. [30], and Namkoong et al. [31]. The reviews included in our meta-review concerned internet-based and/or computerbased eHealth interventions, the only exception being Bender et al.'s [14] review, which looked at smartphone applications only. The eHealth interventions described in the ten reviews concerned both single-component interventions and multicomponent interventions with content that varied considerably. Examples of single- 
Slev, V.N., Mistiaen, P., Pasman, H.R.W., Verdonck-de Leeuw, I.M., Uden-Kraan, C.F. van, Francke, A.L. Effects of eHealth for patients and informal caregivers confronted with cancer: a meta-review. International Journal of Medical Informatics: 2016, 87, 54-67

component interventions are websites that only provide information about the disease or treatments. Multi-component interventions, for example, offer information as well as the possibility to 'chat' with healthcare professionals. It is, however, difficult to conclude if the type of eHealth modality, e.g. internet-based or computer-based, moderates possible effects. Moreover, it is also often difficult to determine whether multi-component interventions are more effective than single-component interventions based on the existing systematic reviews. In the case of multicomponent eHealth interventions, it is difficult to establish which particular component contributes most to an effect on a certain outcome. In this regard, Griffiths et al.'s [15] results are likely to be the most informative, since they separately reviewed the effects of single-component and multi-component interventions.

A surprising finding is that most of the reviews as well as the underlying studies did not focus on patients in a specific disease or treatment stage. Consequently, we do not know whether eHealth is equally effective for patients in the diagnostic, curative and palliative phase of cancer. The effects of eHealth might be different depending on patients' needs for information and support, which may vary during the disease and treatment trajectory. Cancer patients in the curative phase, for example, may be in more need of information about how to cope with late effects of surgery or chemotherapy, while patients with advanced cancer may want information about the self-management of pain and psychological distress. In future research (both at the level of separate intervention studies and the level of systematic reviews), more attention should be given to the effects of eHealth interventions in relation to the disease stage.

We also found that almost none of the reviews considered patients with specific tumor types, while there may be differences in patients' needs for information and support depending on their diagnosis. People with lung cancer for example, may be more in need of information about dyspnea while women with cervical cancer might appreciate information concerning infertility.

Additionally, we discovered a considerable overlap between four reviews in the underlying studies they included. This may be due to the fact that the Comprehensive Health Enhancement Support System for breast cancer patients is the most researched eHealth intervention among the available eHealth interventions. Hence, in some cases, the reported effects and evidence may apply more to breast cancer patients than to patients with other tumor types. This is all the more reason why future research should concentrate on specific tumor types.

Lastly, demographic characteristics such as age or education were not taken into account by the reviews, while such background characteristics might be important since older people or less educated people may have more difficulties with the use of eHealth.

More tailored eHealth interventions may yield stronger effects. However, more research is needed to confirm this hypothesis.

\subsection{Strengths and limitations}

The strengths of this meta-review are: (1) sensitive search strategies with few limitations and in a range of literature databases; (2) assessment of the methodological quality, which led to the exclusion of systematic reviews of poor quality; (3) a broad range of eHealth interventions and outcomes studied in the reviews included. The latter, however, is also a limitation as it shows heterogeneity. 
Slev, V.N., Mistiaen, P., Pasman, H.R.W., Verdonck-de Leeuw, I.M., Uden-Kraan, C.F. van, Francke, A.L. Effects of eHealth for patients and informal caregivers confronted with cancer: a meta-review. International Journal of Medical Informatics: 2016, 87, 54-67

Therefore, findings have to be interpreted with prudence. We decided to perform a meta-review since we believed many systematic reviews concerning eHealth for patients and informal caregivers had already been published. While this assumption was correct for patients, it was not for informal caregivers. None of the reviews we looked at studied eHealth targeting informal caregivers. Given this, it may have been more sensible to separately review eHealth for informal caregivers in a systematic review instead of a meta-review.

\section{CONCLUSIONS}

This meta-review based on systematic reviews found evidence for the effect of eHealth on cancer patients' knowledge, information competence, and perception of the support they received. For effects on other patient outcomes the evidence is inconsistent, limited, or seems to point to no effect.

None of the systematic reviews focused on eHealth for informal caregivers of cancer patients. Future systematic reviews should provide insight into the effects of eHealth in informal caregivers in particular. To further demonstrate effects in patients and/or informal caregivers, researchers should separately analyze and compare singlecomponent and multi-component eHealth interventions. Additionally, future reviews should focus more on comparing the effects of eHealth in different groups of patients, distinguished by treatment stage (curative or palliative) and tumor types, for instance.

\section{Summary points}

What was already known on the topic

- eHealth might complement professional face-to-face support to people confronted with cancer.

- A variety of eHealth interventions for people confronted with cancer and which focuses on information provision and (peer) support in managing physical and emotional problems, decision-making, and self-management, have already been developed.

- Several systematic reviews on effects of eHealth have already been published. A comprehensive overview of evidence for effects of eHealth on cancer patients and their informal caregivers is absent.

What this study added to our knowledge

- Paucity of high quality systematic reviews.

- Demonstration of (lack of) evidence for effects of eHealth on different outcomes like perceived support, knowledge and information competence, psychological outcomes and decision-making.

- Identification of lacunas in the existent evidence base regarding effects on:

- informal caregivers of cancer patients;

- patients with specific tumor types;

- cancer patients in a specific treatment or disease stage.

- Recommendation to focus future research on the identified lacunas and separately study different types of eHealth interventions, like single-component and multicomponent eHealth interventions.

\section{CONFLICT OF INTEREST}

None. 
Slev, V.N., Mistiaen, P., Pasman, H.R.W., Verdonck-de Leeuw, I.M., Uden-Kraan, C.F. van, Francke, A.L. Effects of eHealth for patients and informal caregivers confronted with cancer: a meta-review. International Journal of Medical Informatics: 2016, 87, 54-67

\section{Authors' CONTRIBUtions}

VNS, PM and ALF were responsible for the design of this study. VNS and PM designed the search strategies and performed the literature searches. VNS, HRP and ALF performed the review selection, and VNS and ALF assessed the methodological quality of the reviews. VNS, CFU, IMVdL and ALF were responsible for the data extraction, analysis, and/or interpretation of the data. VNS and ALF drafted this manuscript in cooperation with PM, HRP, CFU and IMVdL. All authors read and approved the manuscript.

\section{ACKNOWLEDGEMENTS}

This study was supported by ZonMw, The Netherlands Organisation for Health Research and Development, grant number 520002001.

\section{APPENDIX A. SUPPLEMENTARY DATA}

The following are Supplementary data to this article:

\section{REFERENCES}

[1] J.E. Esther Kim, M.J. Dodd, B.E. Aouizerat, et al. A review of the prevalence and impact of multiple symptoms in oncology patients J. Pain Symptom Manag., 37 (April (4)) (2009), pp. 715-736 http://dx.doi.org/10.1016/j.jpainsymman.2008.04.018

[2] A. Girgis, S. Lambert, C. Johnson, et al. Physical, psychosocial, relationship, and economic burden of caring for people with cancer: a review J. Oncol. Pract., 9 (July (4)) (2013), pp. 197-202 http://dx.doi.org/10.1200/JOP.2012.000690

[3] A.G. Ekeland, A. Bowes, S. Flottorp Effectiveness of telemedicine: a systematic review of reviews Int. J. Med. Inform., 79 (November (11)) (2010), pp. 736-771 http://dx.doi.org/10.1016/j.ijmedinf.2010.08.006

[4] A.D. Black, J. Car, C. Pagliari, et al. The impact of eHealth on the quality and safety of health care: a systematic overview PLoS Med., 8 (January (1)) (2011), p. e1000387 http://dx.doi.org/10.1371/journal.pmed.1000387

[5] G. Eysenbach What is e-health? J. Med. Internet. Res., 3 (June (2)) (2001), p. e20 http://dx.doi.org/10.2196/jmir.3.2.e20

[6] V. Smith, D. Devane, C.M. Begley, et al. Methodology in conducting a systematic review of systematic reviews of healthcare interventions BMC Med. Res. Methodol., 11 (2011), p. $15 \mathrm{http}: / / \mathrm{dx}$.doi.org/10.1186/1471-2288-11-15

[7] A.D. Oxman, G.H. Guyatt, J. Singer, et al. Agreement among reviewers of review articles J. Clin. Epidemiol., 44 (1991), pp. 91-98 http://dx.doi.org/10.1016/0895-4356(91)90205-n

[8] A.D. Oxman, G.H. Guyatt Validation of an index of the quality of review articles

$\mathrm{J}$ Clin Epidemiol, 44 (1991), pp. 1271-1278 http://dx.doi.org/10.1016/0895-4356(91)90160-b

[9] P. Katrak, A.E. Bialocerkowski, N. Massy-Westropp, et al. A systematic review of the content of critical appraisal tools BMC Med. Res. Methodol., 4 (2004), p. 22 http://dx.doi.org/10.1186/1471-2288-4-22

[10] P. Mistiaen, A.L. Francke, E. Poot Interventions aimed at reducing problems in adult patients discharged from hospital to home: a systematic meta-review BMC Health Serv. Res., 7 (2007), p. 47 http://dx.doi.org/10.1186/1472-6963-7-47

[11] A.L. Francke, M.C. Smit, A.J. de Veer, et al. Factors influencing the implementation of clinical guidelines for health care professionals: a systematic meta-review BMC Med. Inform. Decis. Mak., 8 (September (38)) (2008) http://dx.doi.org/10.1186/1472-6947-8-38

[12] E.M. Steultjens, J. Dekker, L.M. Bouter, et al. Occupational therapy for stroke patients: a systematic review Stroke, 34 (3) (2003), pp. 676-687 http://dx.doi.org/10.1161/01. STR.0000057576.77308.30

[13] L. Beatty, S. Lambert A systematic review of internet-based self-help therapeutic interventions to improve distress and disease-control among adults with chronic health 
Slev, V.N., Mistiaen, P., Pasman, H.R.W., Verdonck-de Leeuw, I.M., Uden-Kraan, C.F. van, Francke, A.L. Effects of eHealth for patients and informal caregivers confronted with cancer: a meta-review. International Journal of Medical Informatics: 2016, 87, 54-67

conditions Clin. Psychol. Rev., 33 (June (4)) (2013), pp. 609-622

http://dx.doi.org/10.1016/j.cpr.2013.03.004

[14] J.L. Bender, R.Y. Yue, M.J. To, et al. A lot of action, but not in the right direction: systematic review and content analysis of smartphone applications for the prevention, detection, and management of cancer J. Med. Internet Res., 15 (December (12)) (2013), p. e287 http://dx.doi.org/10.2196/jmir.2661

[15] K.M. Griffiths, A.L. Calear, M. Banfield Systematic review on Internet Support Groups (ISGs) and depression (1): Do ISGs reduce depressive symptoms? J. Med. Internet Res., 11 (September (3)) (2009), p. e40 http://dx.doi.org/10.2196/jmir.1270

[16] M. Gysels, I.J. Higginson Interactive technologies and videotapes for patient education in cancer care: systematic review and meta-analysis of randomised trials

Support Care Cancer, 15 (1) (2007), pp. 7-20 http://dx.doi.org/10.1007/s00520-006-0112-z

[17] L.M. Hoey, S.C. leropoli, V.M. White, et al. Systematic review of peer-support programs for people with cancer Patient Educ. Couns., 70 (3) (2008), pp. 315-337 http://dx.doi.org/10.1016/j.pec.2007.11.016

[18] Y. Hong, N.C. Peña-Purcell, M.G. Ory Outcomes of online support and resources for cancer survivors: a systematic literature review Patient Educ. Couns., 86 (3) (2012), pp. 288-296 http://dx.doi.org/10.1016/j.pec.2011.06.014

[19] M.A. Johansen, E. Henriksen, A. Horsch, et al. Electronic symptom reporting between patient and provider for improved health care service quality: a systematic review of randomized controlled trials. part 1: state of the art J. Med. Internet Res., 14 (5) (2012), p. e118 http://dx.doi.org/10.2196/jmir.2214

[20] A.M. Ryhänen, M. Siekkinen, S. Sirkku Rankinen, et al. The effects of Internet or interactive computer-based patient education in the field of breast cancer: a systematic literature review Patient Educ. Couns., 79 (1) (2010), pp. 5-13

http://dx.doi.org/10.1016/j.pec.2009.08.005

[21] A. Salonen, A.M. Ryhänen, H. Leino-Kilpi Educational benefits of Internet and computerbased programmes for prostate cancer patients: a systematic review Patient Educ. Couns., 94 (January (1)) (2014), pp. 10-19 http://dx.doi.org/10.1016/j.pec.2013.08.022

[22] F. Ventura, J. Ohlén, I. Koinberg An integrative review of supportive e-health programs in cancer care Eur. J. Oncol. Nurs., 17 (August (4)) (2013), pp. 498-507 http://dx.doi.org/10.1016/j.ejon.2012.10.007

[23] P. Dumrongpakapakorn, K. Hopkins, P. Sherwood, et al. Computer-mediated patient education: Opportunities and challenges for supporting women with ovarian cancer Nurs. Clin. North Am., 44 (September (3)) (2009), pp. 339-354 http://dx.doi.org/10.1016/j.cnur.2009.06.008

[24] G. Eysenbach The impact of the internet on cancer outcomes CA Cancer J. Clin., 53 (2003), pp. 356-371 http://dx.doi.org/10.3322/canjclin.53.6.356

[25] P. Klemm, D. Bunnell, M. Cullen, et al. Online cancer support groups: a review of the research literature Comput. Inform. Nurs., 21 (May-Jun (3)) (2003), pp. 136-142

[26] D.H. Gustafson, R. Hawkins, S. Pingree, et al. Effect of computer support on younger women with breast cancer J. Gen. Intern. Med., 16 (7) (2001), pp. 435-445 http://dx.doi.org/10.1046/j.1525-1497.2001.016007435.x

[27] D.H. Gustafson, F.M. McTavish, W. Stengle, et al. Use and impact of ehealth system by low-income women with breast cancer J. Health Commun., 10 (Suppl. 1) (2005), pp. 195218 http://dx.doi.org/10.1080/10810730500263257

[28] B.R. Shaw, J.Y. Han, T. Baker, et al. How women with breast cancer learn using interactive cancer communication systems Health Educ. Res., 22 (1) (2007), pp. 108-119 http://dx.doi.org/10.1093/her/cyl051

[29] M. Wise, J.Y. Han, B. Shaw, et al. Effects of using online narrative and didactic information on healthcare participation for breast cancer patients Patient Educ. Couns., 70 (3) (2008), pp. 348-356 http://dx.doi.org/10.1016/j.pec.2007.11.009

[30] S. Farnham, L. Cheng, L. Stone, et al. HutchWorld: clinical study of computer-mediated social support for cancer patients and their caregivers. In: Proceedings of the SIGCHI Conference on Human Factors in Computing Systems 2002:ACM.

[31] K. Namkoong, L.L. DuBenske, B.R. Shaw, et al. Creating a bond between caregivers online: effect on caregivers' coping strategies J. Health Commun., 17 (2) (2012), pp. 125140 http://dx.doi.org/10.1080/10810730.2011.585687 
Slev, V.N., Mistiaen, P., Pasman, H.R.W., Verdonck-de Leeuw, I.M., Uden-Kraan, C.F. van, Francke, A.L. Effects of eHealth for patients and informal caregivers confronted with cancer: a meta-review. International Journal of Medical Informatics: 2016, 87, 54-67

\section{TABLES AND FIGURES}

Table 1: Methodological assessment scores.

\begin{tabular}{|l|l|}
\hline Reference & $\begin{array}{l}\text { Methodological assessment } \\
\text { scores }\end{array}$ \\
\hline $\begin{array}{l}\text { Beatty and Lambert } \\
\text { [13] }\end{array}$ & 5 \\
\hline Bender et al. [14] & 3 \\
\hline Griffiths et al. [15] & 3 \\
\hline $\begin{array}{l}\text { Gysels and Higginson } \\
\text { [16] }\end{array}$ & 4,5 \\
\hline Hoey et al. [17] & 4,5 \\
\hline Hong et al. [18] & 3 \\
\hline Johansen et al. [19] & 3,5 \\
\hline Ryhanen et al. [20] & 3,5 \\
\hline Salonen et al. [21] & 3,5 \\
\hline Ventura et al. [22] & 3 \\
\hline
\end{tabular}


Slev, V.N., Mistiaen, P., Pasman, H.R.W., Verdonck-de Leeuw, I.M., Uden-Kraan, C.F. van, Francke, A.L. Effects of eHealth for patients and informal caregivers confronted with cancer: a meta-review. International Journal of Medical Informatics: 2016, 87, 54-67

FIG. 1. FLOWCHART OF REVIEW SELECTION PROCESS.

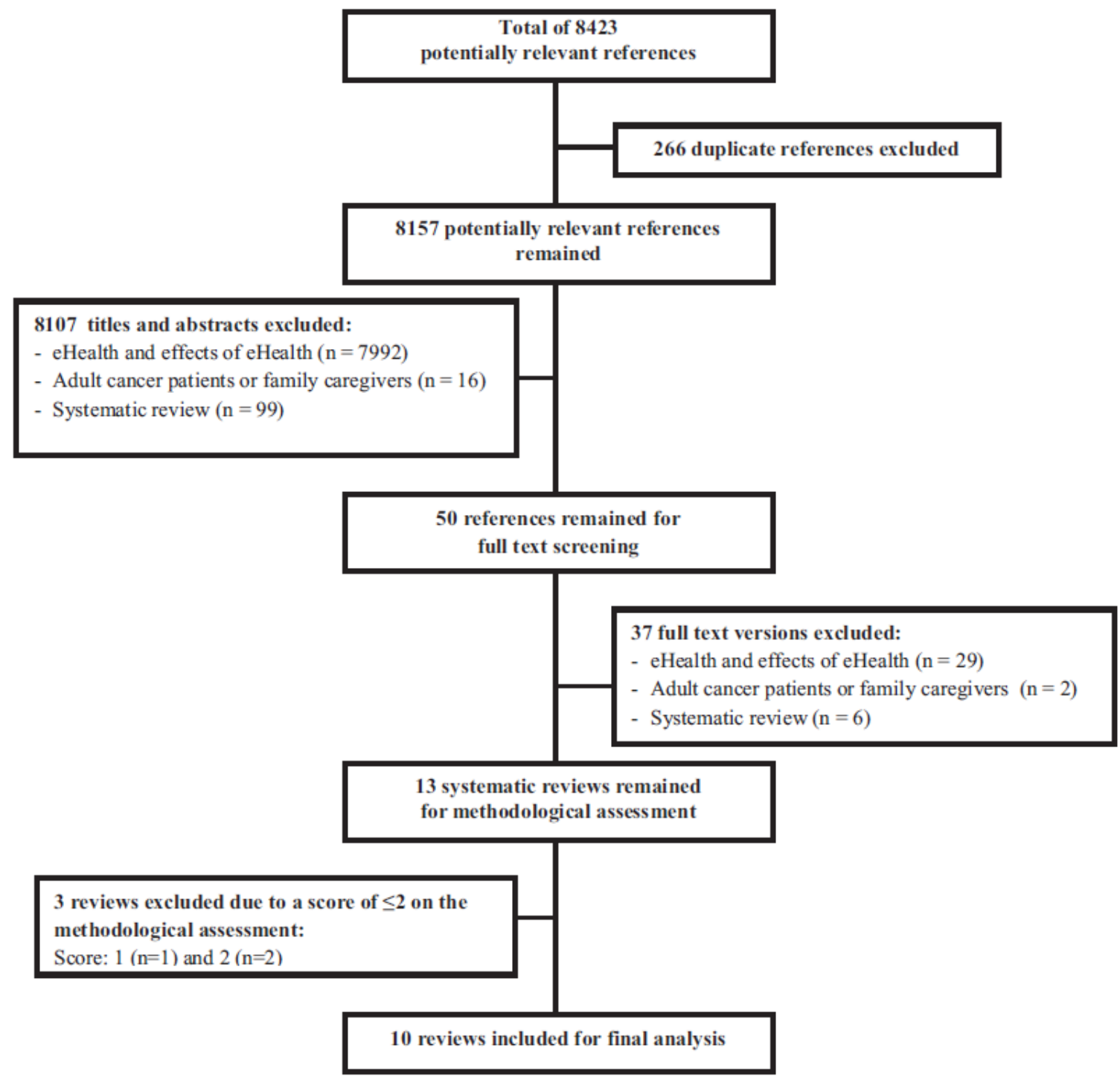


Slev, V.N., Mistiaen, P., Pasman, H.R.W., Verdonck-de Leeuw, I.M., Uden-Kraan, C.F. van, Francke, A.L. Effects of eHealth for patients and informal caregivers confronted with cancer: a

\section{Box 1: Principles of Best Evidence Synthesis Evidence}

Consistent effects on a specific outcome in at least one high quality systematic review, based on at least two underlying effect studies.

This is under the condition that no more than two moderate quality systematic reviews or no other high quality systematic review report conflicting findings.

OR

Consistent effects on a specific outcome in at least three moderate quality systematic reviews, based on at least two underlying effect studies per systematic review.

This is under the condition that no high quality systematic review or no more than two other moderate quality systematic reviews report conflicting findings.

\section{Indications of evidence}

Consistent effects on a specific outcome in one high quality systematic review, based on one underlying effect study.

This is under the condition that no more than two moderate quality systematic reviews and/or no other high quality review report conflicting findings.

OR

Consistent effects on a specific outcome in one moderate qual- ity systematic reviews.

This is under the condition that no high quality systematic review and/or no more than two other moderate quality sys- tematic reviews report conflicting or inconsistent findings.

\section{Inconsistent findings}

Inconsistent effects on a specific outcome, when findings of a (number of) high quality systematic review(s) are being contra- dicted by a (number of) other high quality systematic review(s). OR Inconsistent effects on a specific outcome, when findings of a (number of) moderate quality systematic review(s) are being contradicted by a (number of) other moderate quality system- atic review(s).

\section{No evidence}

No effects on a specific outcome when a (number of) high quality systematic review(s) did not find effects.

This is under the condition that no other (number of) high qual- ity systematic review(s) or no more than two moderate quality systematic reviews report conflicting findings.

OR

No effects on a specific outcome when three or more moderate quality systematic reviews did not find effects. This is under the condition that no other systematic review reports conflicting findings.

\section{No research found}

None of the included reviews examined effects on a specific outcome. 
Table 2

Characteristics of eHealth interventions in reviews included.

\begin{tabular}{|c|c|c|c|c|}
\hline $\begin{array}{l}\text { Reference and } \\
\text { score } \\
\text { methodological } \\
\text { assessment }\end{array}$ & Type of eHealth interventions & Content of eHealth interventions & $\begin{array}{l}\text { eHealth } \\
\text { intervention period }\end{array}$ & $\begin{array}{l}\text { Organizational } \\
\text { setting of eHealth } \\
\text { interventions }\end{array}$ \\
\hline $\begin{array}{l}\text { Beatty and } \\
\text { Lambert [13] } \\
5\end{array}$ & $\begin{array}{l}\text { "Internet-based cognitive-behavior therapy } \\
\text { * Website: asynchronous bulletin board; un-moderated forum. }\end{array}$ & $\begin{array}{l}\text { Information provision } \\
{ }^{*} \text { Information provision: common symptoms and } \\
\text { side-effects (self-help). } \\
\text { Support } \\
\text { *Online peer-support (peer support) } \\
\text { Other } \\
{ }^{*} \text { Six coping-skills training exercises based on Cognitive } \\
\text { Behavior Therapy principles (self-help). }\end{array}$ & * 12 wks & Not reported \\
\hline $\begin{array}{l}\text { Bender et al. } \\
\text { [14] } \\
3\end{array}$ & $\begin{array}{l}\text { Examples of 8/295 cancer-focused smartphone applications, categorized per purpose: } \\
\text { - awareness: Pink Ribbon Breast Cancer Wallpaper; } \\
\text { - information provision: Cancer iOncolex; } \\
\text { - fundraising: The Ride to Conquer Cancer; } \\
\text { - promotion organizations: Conquer Cancer Foundation; } \\
\text { - early detection: Skin Cancer- The Most Accurate Skin Cancer Detector on } \\
\text { iPhone; } \\
\text { - disease management: Cancer Net; } \\
\text { - prevention: iEat for Life: Prostate Cancer; } \\
\text { - peer support: Breast Cancer Connect } \\
\text { Methods per purpose: } \\
\text { - awareness: text, images, games, interactive activities (Quiz); } \\
\text { - information provision: text, eBook, images, videos, search functionality; } \\
\text { - fundraising: fundraising tools; } \\
\text { - early detection: text, images, videos, monitoring tools: capture, track images; } \\
\text { risk score questionnaires; } \\
\text { - promotion organizations: text; } \\
\text { - disease management: appointment tools, lab results storage, } \\
\text { self-monitoring/tracking tools, communication tools, question list guidance } \\
\text { patient-healthcare professional communication, recording possibilities; } \\
\text { - prevention: text; images; interactive activities (Quiz); } \\
\text { - peer support: asynchronous communication tools, GPS locator tracking other } \\
\text { members, text, audio. } \\
{ }^{*} \text { Top three multimedia formats: visual media-only (36.7\%, 108/295); text-only } \\
\text { (28.9\%, 83/295); text and visual media (22.6\%, 65/295). } \\
{ }^{*} \text { Combination multi-media content (31.5\%, 93/295) }\end{array}$ & $\begin{array}{l}\text { Information provision } \\
\text { *Information provision: disease, diagnosis, symptoms, } \\
\text { treatment, prevention, screening, alternative therapy, } \\
\text { managing physical, behavioral, psychosocial aspects, } \\
\text { charitable organizations. } \\
{ }^{*} \text { Communication with healthcare team } \\
{ }^{*} \text { Promotion exercise } \\
{ }^{*} \text { Promotion healthy eating behaviors } \\
\text { Support } \\
\text { * Reminders; screening, medication, appointments } \\
\text { * Online peer support; personal stories. } \\
\text { Other } \\
\text { * Skills training/Instructions } \\
\text { * Monitoring screening results } \\
\text { * (physical and psychosocial) Symptom and medication, } \\
\text { medical costs tracking. }\end{array}$ & Not reported & Not reported \\
\hline $\begin{array}{l}\text { Griffiths et al. } \\
{[15]} \\
3\end{array}$ & $\begin{array}{l}\text { Internet Support Group: single component interventions: } \\
\text { - Web-based structured newsgroup moderated psychologist; topic discussion, } \\
\text { once a week } \\
\text { - Chat room sessions with experienced leader therapist and } 24 \mathrm{~h} \text { access } \\
\text { bulletin board } \\
\text { - Public bulletin board, moderated } \\
\text { - Public bulletin board, no information about moderator status } \\
\text { - Public bulletin board } \\
\text { Internet Support Group: multi component interventions: } \\
\text { - Bulletin board, moderated by health professional and art/poetry forum }\end{array}$ & $\begin{array}{l}\text { Single-component interventions } \\
\text { Support: } \\
\text { * Providing emotional support } \\
{ }^{*} \text { In some instances, content was not explicitly reported. } \\
\text { Multi-component interventions } \\
\text { Information provision } \\
{ }^{*} \text { Information provision } \\
\text { *Information + monitoring via electronic questionnaire. } \\
\text { Support } \\
{ }^{*} \text { Peer support }\end{array}$ & $\begin{array}{l}\text { Various: } \\
* 12 \text { wks } \\
* 16 \text { wks, } 1,5 \text { hrs. } \\
\text { chat room } \\
\text { *6-8 mths } \\
\text { * variable duration } \\
\text { membership: mean } \\
247 \text { days; } 44-1001 \\
\text { days } \\
\text { * } 6 \text { wks }\end{array}$ & Not reported \\
\hline
\end{tabular}

Peer support

${ }^{*}$ Structured coping skills exercises (stress management, assertiveness + structured problem solving training).

Various:
* 12 wks
* 16 wks, 1,5 hrs.
chat room
* $6-8$ mths
* variable duration
membership: mean
247 days; $44-1001$
days
* 6 wks 
Table 2 (Continued)

\begin{tabular}{|c|c|c|c|c|}
\hline $\begin{array}{l}\text { Reference and } \\
\text { score } \\
\text { methodological } \\
\text { assessment }\end{array}$ & Type of eHealth interventions & Content of eHealth interventions & $\begin{array}{l}\text { eHealth } \\
\text { intervention period }\end{array}$ & $\begin{array}{l}\text { Organizational } \\
\text { setting of eHealth } \\
\text { interventions }\end{array}$ \\
\hline $\begin{array}{l}\text { Gysels } \\
\text { and } \\
\text { Higginson [16] } \\
4,5\end{array}$ & $\begin{array}{l}\text { * Comprehensive Health Enhancement Support System (CHESS); 'Take-away } \\
\text { tool' providing cancer information, decision making + emotional support } \\
\text { * Computer-based information system; Device for improvement of } \\
\text { information transfer and facilitating consent process, during consultation. It } \\
\text { provides: general information (intervention 1); personalized information via } \\
\text { link between device and patients' medical records (1/2 of patients also } \\
\text { accessed general information) (intervention 2) } \\
\text { * Interactive video disk; Device for improvement of information transfer, } \\
\text { during consultation. Provides cancer information, treatment choices, explores } \\
\text { issues of uncertainty, variations in practice. Operated step-by-step under } \\
\text { professional's supervision } \\
\text { *Interactive multimedia program/computer-assisted instruction; Proactive } \\
\text { device delivered before and for preparation of consultation. Presentation of } \\
\text { information in following formats: text, graphics, narration, music, audio and } \\
\text { video clips } \\
\text { * Interactive decision board during consultations; Device for improvement of } \\
\text { information transfer, during consultation. Visual aid with written and } \\
\text { graphical information. Operated step-by-step under professional's supervision }\end{array}$ & $\begin{array}{l}\text { Information provision } \\
\text { *Some form of research-based information } \\
\text { "Research-based information: explanation relevant terms } \\
\text { and concepts; current literature overview; explanation of } \\
\text { RCTs; 'Instant Library' with scientific and popular press } \\
\text { articles. } \\
\text { Support } \\
\text { * Decision-making tools: Tailored information based on } \\
\text { patient provided personal details. Information on } \\
\text { treatment options, risks and benefits, clarification of values } \\
\text { and understanding outcomes } \\
\text { "Forms of video segments of experiences of others } \\
{ }^{*} \text { Provision of support groups or expert advice } \\
{ }^{*} \text { Awareness raising/empowerment by: repeatedly } \\
\text { encouraging to take active role in decision making and } \\
\text { disease management; identification of resources like } \\
\text { descriptions and contacts services. }\end{array}$ & Not reported & $\begin{array}{l}\text { Various: } \\
{ }^{*} \text { Home-based } \\
{ }^{*} \text { Before } \\
\text { consultation } \\
{ }^{*} \text { During } \\
\text { consultation }\end{array}$ \\
\hline $\begin{array}{l}\text { Hoey et al. [17] } \\
4,5\end{array}$ & $\begin{array}{l}\text { * Peer-support programs } \\
\text { * (Facilitated) Bulletin board } \\
\text { * Chat room format } \\
\text { * Structured group, professionally facilitated } \\
\text { * Asynchronous support groups }\end{array}$ & $\frac{\text { Support }}{{ }^{*} \text { Peer support }}$ & $\begin{array}{l}\text { Various: } \\
\text { * Ongoing, } 24 \mathrm{~h} \\
\text { *24h, } 1 \mathrm{yr} \\
\text { *24h, } 12 \mathrm{wks} \\
\text { *24h, } 6 \mathrm{mths} \\
\text { * } 1 \mathrm{p} \mathrm{wk}, 16 \text { wks }\end{array}$ & $\begin{array}{l}\text { * Home } \\
\text { *In some instances, } \\
\text { organizational } \\
\text { setting was not } \\
\text { reported }\end{array}$ \\
\hline $\begin{array}{l}\text { Hong et al. [18] } \\
3\end{array}$ & $\begin{array}{l}\text { * Home-based computer system (CHESS) } \\
\text { *(Privately accessed) online bulletin boards } \\
\text { * Online cancer forum } \\
\text { * Internet/online/electronic support group } \\
\text { * General Internet use: especially online/offline communication stimulated by } \\
\text { online communication and online information seeking } \\
\text { * Internet Discussion group } \\
\text { * Online breast cancer discussion board } \\
\text { * Peer support system: online discussion, chat room, personal message system } \\
\text { (for intervention group) }\end{array}$ & $\begin{array}{l}\text { Information provision } \\
{ }^{*} \text { Information provision on cancer and decision making. } \\
\text { Support } \\
{ }^{*} \text { Online cancer support; mostly online social (emotional or } \\
\text { informational support). } \\
{ }^{*} \text { Peer support }\end{array}$ & $\begin{array}{l}\text { Various: } \\
{ }^{*} 1,5 \mathrm{~h} / \mathrm{wk}, 16 \mathrm{wks} \\
{ }^{*} 12 \mathrm{wks} \\
{ }^{4} 90 \mathrm{~min} / \mathrm{wk}, 30 \\
\text { wks } \\
{ }^{*} 27 \mathrm{wks} \\
{ }^{2} \text { In some instances, } \\
\text { intervention period } \\
\text { was not reported }\end{array}$ & Not reported \\
\hline
\end{tabular}


Table 2 (Continued)

\begin{tabular}{|c|c|c|c|c|}
\hline $\begin{array}{l}\text { Reference and } \\
\text { score } \\
\text { methodological } \\
\text { assessment }\end{array}$ & Type of eHealth interventions & Content of eHealth interventions & $\begin{array}{l}\text { eHealth } \\
\text { intervention period }\end{array}$ & $\begin{array}{l}\text { Organizational } \\
\text { setting of eHealth } \\
\text { interventions }\end{array}$ \\
\hline $\begin{array}{l}\text { Johansen et al. } \\
{[19]} \\
3,5\end{array}$ & $\begin{array}{l}\text { *Electronic Self-Report Assessment-Cancer (ESRA-C): color graphical } \\
\text { summary of participant's self-reported symptoms and quality of life issues } \\
\text { with predetermined thresholds flagged was printed and handed to clinician } \\
\text { immediately before targeted clinic visit. No recommendations offered } \\
\text { * Touch-screen survey filled out before oncologist visit. Computer scored } \\
\text { answers. Printed summary of report in patient's file for consideration during } \\
\text { consultation. Suggested strategies for managing identified issues were } \\
\text { included } \\
\text { "All patients scheduled for outpatient visit used system on tablet computer for } \\
\text { reporting symptoms and preferences before consultation. For clinicians, } \\
\text { system highlighted patient experienced symptoms incl. severity, degree of } \\
\text { bother, importance for patients. Information was printed and handed to the } \\
\text { patient and clinician } \\
\text { *Use of “Choice"; interactive tailored patient assessment tool, touchpad tablet } \\
\text { PC, for symptom assessments prior to inpatient and outpatient visits. } \\
\text { Assessment summary, displaying patient's self-reported symptoms, problems } \\
\text { and distress in rank order of patient's need for support, provided to physicians } \\
\text { and nurses } \\
\text { *'Completion of touch-screen Health-related quality of life questionnaires in } \\
\text { waiting room before every encounter. Summary handed to physicians. } \\
\text { * Mobile phone system (ASyMS) used in morning, evening and any time } \\
\text { patients felt unwell on days } 1-14 \text { following first } 4 \text { chemotherapy cycles. } \\
\text { Completion electronic symptom questionnaire on mobile phone, incl. } \\
\text { temperature. Patients immediately received written feedback on mobile } \\
\text { phone. Clinicians were advised to contact patients within } 1 \mathrm{~h} \text { after receiving } \\
\text { red alert. The system's alert to physician is based on risk model }\end{array}$ & $\begin{array}{l}\text { Support } \\
{ }^{*} \text { Enhancing patient-provider communication with } \\
\text { electronic self-report assessment for cancer. } \\
{ }^{*} \text { Supporting shared decision making } \\
{ }^{*} \text { Improving communication and patient well-being } \\
{ }^{*} \text { In some instances, content was not reported. } \\
\text { Other } \\
{ }^{*} \text { Monitoring: management of chemotherapy-related } \\
\text { toxicity. }\end{array}$ & $\begin{array}{l}\text { Various: } \\
\text { * } 2 \text { visits (before } \\
\text { treatment, } 4-6 \text { wks } \\
\text { later) } \\
\text { * Before visit, } 4 \\
\text { times } \\
\text { * } 1 \text { consultation } \\
\text { * Up to } 1 \text { yr (once } \\
\text { per encounter } \\
\text { during treatment, } \\
\text { once week during } \\
\text { hospital stay, once } \\
\text { outpatient visit in } \\
\text { up to } 4 \text { visits) } \\
\text { * Approx. } 6 \text { mths } \\
\text { * } 4 \text { cycles } \\
\text { chemotherapy } \\
\text { (12-16 wks) }\end{array}$ & $\begin{array}{l}\text { Various: } \\
\text { * Inside Clinic } \\
\text { * Outside/home }\end{array}$ \\
\hline
\end{tabular}

red alert. The system's alert to physician is based on risk model

Device:

* Computer/tablet 
Table 2 (Continued)

Reference and

Type of eHealth interventions

Content of eHealth interventions

eHealth

intervention period

Organizational

score

assessment

Ryhanen et al.

[20]
Internet education programs

* Comprehensive Health Enhancement Support System (CHESS)

* Self-guided Internet-Based Coping-skills training program to manage symptoms of treatments

Different educational interactive computerized programs

* Options for Treating Breast Cancer

* The information and decision profiles

* Breast Cancer Genetics Computer Program

* The Computerized Decision Aid

* Retratos de la Vida Real (Photographs of Real Life)

* Common use of Internet

Computer-based (interactive or multimedia) programs

* Interactive soap opera

* CD-ROM

Interactive multimedia program

Interactive computer system/interface

Internet-based programs

Home computer with modem connection to a central server for

communication

* (a series of) Webpage(s)

"Common use of Internet

* Possibilities to chat with other patients or pose questions to health

professionals (Internet-based programs)

Text related to breast cancer

* Images and sound

* Audio and videos

* Decision aids

Salonen et al. $\quad$ * Patient Information Programme: computer program, touchscreen or mouse

Salonent

$[21,5$ format

*Virtual Conversations model: voice-activated interactive computer system. Virtual communication with virtual doctor

* IT-based informational support: CD-ROM and websites

* Interactive Health communication: CD-ROM and websites

* Nurse-Driven Intervention: video

* Internet: website, Database of Individual Patient Experiences-website

* Multimedia features integrate audio, video and computer technology
Information provision

Patient education/information provision: breast anatomy,

disease, treatment, heredity, prevention, screening.

Support

${ }^{*}$ Decision-making with different treatment

options/intention to go genetic testing.

* Peer-support like stories of other breast cancer patients.

Other

${ }^{*}$ Exercises

nformation provision

* Comprehensive and reliable information provision

${ }^{*}$ Majority of eHealth interventions: providing questions and answers.

Providing knowledge

List of variety of reputable cancer websites. Cancer

specialized CD-ROM.

List reputable cancer websites, either breast/prostate

cancer. Cancer specialized CD-ROM.

${ }^{*}$ Modules for prostate and breast cancer. Also module

hypertension, testis cancer, cervix, bowel.

Support

${ }^{*}$ Help with (informed) decision-making treatment

* Providing psychosocial support

* Providing symptom management strategies

* Psycho educational strategies

Other

* Tracking quality of life-problems and psycho-educational

trategies with an assessment

Measuring decision and information preferences
Not reported
Various:

* Multiple viewing:

every month

during 6 mths,

unlimited acces

* Single viewing

* In some instances,

intervention p

was not reported

hospital

*Patients' home

* Partners and

spouses in same

room, without eac

other's input

organizational
setting was not

reported 
* Prostate Interactive Educational System (PIES); construction not based on needs assessment of target population, user-driven, contains text, audio,

video, pictures/graphics and computer-based feedback only

Comprehensive Health Enhancement Support System (CHESS): construction based on needs assessment of target population, user-driven, contains text. audio, video, pictures/graphics and both human and computer-based feedback * Virtual Conversations; construction not based on needs assessment of target population, user-driven, contains audio, video and computer-based feedback only

* Interactive Digital Education Aid (IDEA); construction based on needs assessment of target population, user-driven, contains text, audio, video, pictures/graphics and no interactivity in form of feedback

"Computerized Multimedia Interactive Patient Education Aid (CPtDA); construction not based on needs assessment of target population, user-driven, contains text, audio, video, pictures/graphics and computer-based feedback only

* Interactive Shared Decision-Making (DM) Program; construction not based on needs assessment of target population, user-driven, contains text, audio, video, pictures/graphics and no interactivity in form of feedback

"Multimedia Education Program (MEP); construction not based on needs assessment of target population, not user-driven, contains audio, video, pictures/graphics and no interactivity in form of feedback

* Oncology Interactive Educational Series (OIES); construction not based on needs assessment of target population, user-driven, does not contain text audio, video, pictures/graphics and interactivity in form of feedback

${ }^{*}$ CD-ROM Educational Aid; construction not based on needs assessment of

target population, user-driven, contains audio, video, pictures/graphics and no interactivity in form of feedback

* Help with Adjustment to Alopecia by Imaging Recovering (HAAIR);

construction not based on needs assessment of target population, user-driven, contains video and computer-based feedback only. Other multimedia features are not applicable.

The Interactive Breast Cancer CDROM; construction based on needs assessment of target population, user-driven, contains text, audio, video and computer-based feedback only

* The Understanding Cancer CD-ROM; construction not based on needs assessment of target population, user-driven, contains text, audio, video, pictures/graphics and computer-based feedback only

*WebChoice; construction based on needs assessment of target population, user-driven, contains text, audio, video, pictures/graphics and both human + computer-based feedback

Tool; construction based on needs assessment of riven contains text and no interactivity in form of eedback

"A Guide to Your Visit"; construction not based on needs assessment of target population, not user-driven, contains audio, video and interactivity in form of feedback not applicable

"Interactive Videodisc Module; construction not based on needs assessment of target population, user-driven, contains audio, video and no interactivity in form of feedback

Almost all interventions had format of computer-based tool and were user-driven

* Five underlying studies: intervention based on needs assessment of target population, CHESS, IDEA, The Interactive Breast Cancer CD-ROM, WebChoice and The Computerized Educational Tool
Information provision

"Informational support

Support

Emotional support

* Social support

Decision-making

* Self-care
Organizational

setting of eHealth interventions

Various:

All places

* All places and

research cente 
Table 3

Best evidence synthesis.

\begin{tabular}{|c|c|c|c|c|c|c|c|c|c|c|c|}
\hline Reference & $\begin{array}{l}\text { Salonen } \\
\text { et al. [21] } \\
\text { moderate quality }\end{array}$ & $\begin{array}{l}\text { Beatty and } \\
\text { Lambert [13] } \\
\text { high } \\
\text { quality }\end{array}$ & $\begin{array}{l}\text { Ventura } \\
\text { et al. [22] } \\
\text { moderate quality }\end{array}$ & $\begin{array}{l}\text { Bender } \\
\text { et al. [14] } \\
\text { moderate quality }\end{array}$ & $\begin{array}{l}\text { Johansen } \\
\text { et al. [19] } \\
\text { moderate quality }\end{array}$ & $\begin{array}{l}\text { Hong } \\
\text { et al. [18] } \\
\text { moderate quality }\end{array}$ & $\begin{array}{l}\text { Ryhanen } \\
\text { et al. [20] } \\
\text { moderate quality }\end{array}$ & $\begin{array}{l}\text { Griffiths } \\
\text { et al. [15] } \\
\text { moderate quality }\end{array}$ & $\begin{array}{l}\text { Hoey } \\
\text { et al. [17] } \\
\text { moderate quality }\end{array}$ & $\begin{array}{l}\text { Gysels and } \\
\text { Higginson [16] } \\
\text { moderate quality }\end{array}$ & \\
\hline Outcome category & & & & & & & & & & & Level of Evidence \\
\hline $\begin{array}{l}\text { Knowledge } \\
\text { and Information }\end{array}$ & $+(3)$ & & & & & $\begin{array}{l}+(3) \\
\text { no effects (1) }\end{array}$ & $+(9)$ & & & $+(5)$ & Evidence \\
\hline Support & $+(2)$ & & $\begin{array}{l}+(1) \\
\text { no effects (1) }\end{array}$ & & $+(1)$ & $+(7)$ & $+(3)$ & & $+(1)$ & $+(1)$ & Evidence \\
\hline Decision making & $\begin{array}{l}+(3) \\
-(1)\end{array}$ & & $+(6)$ & & & & $+(2)$ & & & $\begin{array}{l}+(2) \\
\text { no effects (2) }\end{array}$ & $\begin{array}{l}\text { Inconsistent } \\
\text { findings }\end{array}$ \\
\hline $\begin{array}{l}\text { Healthcare participation } \\
\text { and Patient involvemen }\end{array}$ & & & $\begin{array}{l}+(3) \\
\text { no effects (1) }\end{array}$ & & & $+(1)$ & $+(6)$ & & $+(1)$ & $\begin{array}{l}+(1) \\
\text { no effects (2) }\end{array}$ & $\begin{array}{l}\text { Indications of } \\
\text { evidence }\end{array}$ \\
\hline Depression & $+(4)$ & & & & $+(1)$ & $\begin{array}{l}+(4) \\
-(1) \\
\text { no effects (1) }\end{array}$ & no effects (2) & $\begin{array}{l}+(4) \\
\text { no effects (2) }\end{array}$ & $+(3)$ & no effects (1) & $\begin{array}{l}\text { Inconsistent } \\
\text { findings }\end{array}$ \\
\hline Anxiety & & & & & $+(1)$ & & no effects (2) & & $+(2)$ & $\begin{array}{l}+(1) \\
-(1) \\
\text { no effects (2) }\end{array}$ & $\begin{array}{l}\text { Inconsistent } \\
\text { findings }\end{array}$ \\
\hline $\begin{array}{l}\text { Psychological } \\
\text { wellbeing }\end{array}$ & $+(3)$ & no effects (1) & & & $\begin{array}{l}+(1) \\
\text { no effects (1) }\end{array}$ & $\begin{array}{l}+(9) \\
-(1) \\
\text { no effects }(4)\end{array}$ & & $+(1)$ & $\begin{array}{l}+(1) \\
-(1)\end{array}$ & & $\begin{array}{l}\text { Inconsistent } \\
\text { findings }\end{array}$ \\
\hline Quality of life & $+(2)$ & no effects (1) & $\begin{array}{l}+(4) \\
\text { no effects (1) }\end{array}$ & & $+(1)$ & $\begin{array}{l}+(1) \\
-(1) \\
\text { no effects (1) }\end{array}$ & & & no effects (1) & $+(1)$ & $\begin{array}{l}\text { Inconsistent } \\
\text { findings }\end{array}$ \\
\hline Health status & & $+(1)$ & $\begin{array}{l}+(4) \\
\text { no effects (2) }\end{array}$ & & & no effects (1) & & & & $+(1)$ & $\begin{array}{l}\text { Indications of } \\
\text { evidence }\end{array}$ \\
\hline Physical wellbeing & & no effects (1) & & & & $\begin{array}{l}+(1) \\
\text { no effects (1) }\end{array}$ & & & $+(1)$ & & No evidence \\
\hline Functional wellbeing & & & & & & no effects (1) & & & & & No evidence \\
\hline
\end{tabular}

+ Positive effects; -Negative effects; () Number of underlying studies in review included. 


\section{Supplementary material; Search strategy PubMed}

For the development and adaption of the search strategies, databases' thesaurus terms for eHealth, cancer, systematic review and meta-analysis or specific 'systematic review filters' were used, as well as free text words describing eHealth.

\section{Search Strategy for PubMed}

(telecommunications[Majr] OR "Medical Informatics/education"[Mesh] OR "Medical Informatics/nursing"[Mesh] OR "Medical Informatics/psychology"[Mesh] OR Computer Communication Networks[Majr] OR educational technology[Majr] OR Biomedical technology[Majr] OR Mobile applications[MeSH Terms] OR electronic health records[Majr] OR Health Records, Personal[MeSH Terms] OR Telenursing[MeSH Terms] OR telemedicine[tiab] OR tele?medicine[tiab] OR telehealth[tiab] OR ehealth[tiab] OR e?health[tiab] OR mhealth[tiab] OR m?health[tiab] OR "mobile health" OR telecare[tiab] OR tele?care[tiab] OR ecare[tiab] OR e?care[tiab] OR app care OR teleconsult*[tiab] OR tele?consult*[tiab] OR econsult*[tiab] OR e?consult*[tiab] OR videoconsult* OR video?consult*[tiab] OR telecommunicat*[tiab] OR tele?communicat*[tiab] OR ecommunicat* OR e?communicat*[tiab] OR electronic communicat* OR videocommunicat* OR video?communicat*[tiab] OR telemonitor*[tiab] OR tele?monitor*[tiab] OR e?support[tiab] OR telesupport[tiab] OR "health technology" OR "health care technology" OR wireless[tiab] OR telenurs*[tiab] OR tele?nurs*[tiab] OR "mobile applications" OR e?coach*[tiab] OR elearn*[tiab] OR e?learn*[tiab] OR web?base*[tiab] OR email*[ti] OR e?mail*[ti] OR smartphon*[tiab] OR smart?phon*[tiab] OR mobile phone* OR "tablet computer" OR "tablet computers" OR iphone*[tiab] OR ipad*[tiab] OR text?messag*[tiab] OR internet*[ti] OR online*[tiab] OR "health 2.0" OR tele?health[tiab])

\section{AND}

(cancer[Majr] OR neoplasms[Majr] OR medical oncology[Majr] OR carcinoma[Majr] OR Sarcoma [Majr] OR metastasis[Majr] OR cancer*[tiab] OR neoplasm*[tiab] OR "medical oncology"[tiab] OR 
oncolog*[tiab] OR tumor*[tiab] OR carcinom*[tiab] OR metastas*[tiab] OR Sarcom*[tiab] OR leukem*[tiab] OR leucem*[tiab] OR hodgkin*[tiab] OR lymphom*[tiab])

AND

((((Meta-Analysis[ptyp] OR Review[ptyp] OR systematic[sb]))) OR ((systematic review[ti] OR metaanalysis[pt] OR meta-analysis[ti] OR systematic literature review[ti] OR (systematic review[tiab] AND review[pt]) OR consensus development conference[pt] OR practice guideline[pt] OR cochrane database syst rev[ta] OR acp journal club[ta] OR health technol assess[ta] OR evid rep technol assess summ[ta] OR drug class reviews[ti]) OR (clinical guideline[tw] AND management[tw]) OR ((evidence based[ti] OR evidence-based medicine[mh] OR best practice*[ti] OR evidence synthesis[tiab]) AND (review[pt] OR diseases category[mh] OR behavior and behavior mechanisms[mh] OR therapeutics[mh] OR evaluation studies[pt] OR validation studies[pt] OR guideline[pt] OR pmcbook)) OR ((systematic[tw] OR systematically[tw] OR critical[tiab] OR (study selection[tw]) OR (predetermined[tw] OR inclusion[tw] AND criteri*[tw]) OR exclusion criteri*[tw] OR main outcome measures[tw] OR standard of care[tw] OR standards of care[tw]) AND (survey[tiab] OR surveys[tiab] OR overview*[tw] OR review[tiab] OR reviews[tiab] OR search*[tw] OR handsearch[tw] OR analysis[tiab] OR critique[tiab] OR appraisal[tw] OR (reduction[tw] AND (risk[mh] OR risk[tw]) AND (death OR recurrence))) AND literature[tiab] OR articles[tiab] OR publications[tiab] OR publication[tiab] OR bibliography[tiab] OR bibliographies[tiab] OR published[tiab] OR unpublished[tw] OR citation[tw] OR citations[tw] OR database[tiab] OR internet[tiab] OR textbooks[tiab] OR references[tw] OR scales[tw] OR papers[tw] OR datasets[tw] OR trials[tiab] OR meta-analy*[tw] OR (clinical[tiab] AND studies[tiab]) OR treatment outcome[mh] OR treatment outcome[tw] OR pmcbook) NOT (letter[pt] OR newspaper article[pt] OR comment[pt])))) 


\section{Table S1 General and methodological characteristics of reviews included}

\begin{tabular}{|c|c|c|c|c|c|c|}
\hline \multicolumn{5}{|c|}{ General and methodological characteristics of reviews included } & \multicolumn{2}{|c|}{$\begin{array}{l}\text { General and methodological characteristics of underlying } \\
\text { studies in review }\end{array}$} \\
\hline $\begin{array}{l}\text { Reference, } \\
\text { first author's } \\
\text { country of } \\
\text { origin, score } \\
\text { meth. } \\
\text { assessment } \\
\end{array}$ & $\begin{array}{l}\text { Information sources } \\
\text { and dates of coverage }\end{array}$ & Review objectives & Review's eligibility criteria & Synthesis of results & Number and design & Population \\
\hline $\begin{array}{l}\text { Beatty et al. } \\
2013 \\
\text { Australia [13] } \\
5\end{array}$ & $\begin{array}{l}\text { * Embase (period ?) } \\
\text { * MEDLINE (period } \\
\text { ?) } \\
\text { * PsycINFO (period ?) } \\
\text { * CINAHL (1980 - } \\
\text { Dec. 2011) } \\
\text { * Reference lists of } \\
\text { included studies. }\end{array}$ & $\begin{array}{l}\text { To update evidence } \\
\text { and to review } \\
\text { application of internet } \\
\text { to psychological } \\
\text { treatment of distress }\end{array}$ & $\begin{array}{l}\text { Inclusion criteria: Published (or in-press) } 1980 \text { - } \\
\text { December 2011; Adults (18>) with a chronic physical } \\
\text { health condition; Self-help internet-based } \\
\text { psychosocial therapeutic interventions; Outcome } \\
\text { measure: distress, quality of life or wellbeing; RCT, } \\
\text { quasi-randomized trial, feasibility RCT study; } \\
\text { English language. } \\
\text { Exclusion criteria: Conditions included in DSM-IV; } \\
\text { Interventions providing information/education only, } \\
\text { without therapeutic component; Studies examining } \\
\text { computer-based support groups; Case-series and } \\
\text { single group pre-post studies. }\end{array}$ & * Narrative synthesis & $\begin{array}{l}* 23 \text { studies included. Only } \\
1 \text { concerned cancer patients. } \\
* \text { design: quasi experimental. } \\
\text { * conditions: eHealth } \\
\text { intervention vs waitlist control } \\
\text { group }\end{array}$ & $\begin{array}{l}\text { * population: adult patients } \\
\text { with a variety of chronic } \\
\text { diseases. } \\
\text { Only one study concerned } \\
\text { cancer patients: } \\
\text { * tumor type: breast } \\
\text { * disease/clinical stage: already } \\
\text { diagnosed } \\
\text { * gender: only female }\end{array}$ \\
\hline $\begin{array}{l}\text { Bender et al. } \\
2013 \\
\text { Canada [14] } \\
3\end{array}$ & $\begin{array}{l}\text { Canadian and French } \\
\text { mobile application } \\
\text { markets: } \\
\text { * iPhone (App Store) } \\
\text { * Android (Google } \\
\text { Play) } \\
\text { * BlackBerry (App } \\
\text { World) } \\
\text { * Nokia/Symbian } \\
\text { (Ovi) } \\
\text { *Date of searches: } \\
\text { February 14, 2012 } \\
\text { Health literature } \\
\text { databases: } \\
\text { * MEDLINE (1990- } \\
\text { June 18, 2012) }\end{array}$ & $\begin{array}{l}\text { To characterize } \\
\text { purpose and content of } \\
\text { cancer-focused } \\
\text { smartphone } \\
\text { applications available } \\
\text { for use by the general } \\
\text { public and evidence } \\
\text { on their utility or } \\
\text { effectiveness. }\end{array}$ & $\begin{array}{l}\text { Mobile application market } \\
\text { Inclusion criteria: focus on cancer; focus on cancer } \\
\text { patients or survivors, their family caregivers or the } \\
\text { general public concerned about cancer; English- } \\
\text { language interface; Available for smartphones. } \\
\text { Exclusion criteria: Only available on tablet } \\
\text { computers; Aimed at health care professionals; } \\
\text { Applications related to smoking cessation, radiation } \\
\text { exposure, or general symptom management } \\
\text { applications. } \\
\text { Health literature search } \\
\text { Inclusion -part 1: Description of evaluation of mobile } \\
\text { phone applications for cancer patients/survivors, } \\
\text { family caregivers, or the general public; Inclusion of } \\
\text { original data on use of mobile phone applications by } \\
\text { cancer patients/survivors, family caregivers or the } \\
\text { general public; English language. } \\
\text { Inclusion final analysis: Description of evaluation of } \\
\text { a cancer-focused smartphone applications. } \\
\text { Exclusion final analysis: Description of evaluation of: } \\
\text {-basic mobile phone and personal digital assistant }\end{array}$ & $\begin{array}{l}\text { * Coding scheme for describing } \\
\text { purpose of applications, based } \\
\text { on seven identified categories } \\
\text { of applications. } \\
\text { * Applications coded into one } \\
\text { category based on their main } \\
\text { purpose as describes in store } \\
\text { description. }\end{array}$ & $\begin{array}{l}\text { * } 295 \text { cancer-focused } \\
\text { smartphone applications found. } \\
\text { * No studies concerning } \\
\text { evaluation of cancer-focused } \\
\text { smartphone applications found. }\end{array}$ & $\begin{array}{l}\text { * population: different groups } \\
\text { of people: patients; cancer } \\
\text { survivors; family caregivers; } \\
\text { general public } \\
\text { * tumor type: breast; skin; } \\
\text { prostate; lung; colorectal; } \\
\text { pancreatic; cervical; ovarian; } \\
\text { testicular; liver; kidney; brain; } \\
\text { pediatric cancers; hematologic } \\
\text { cancers; female cancers; cancer } \\
\text { in general. } \\
\text { * disease/clinical stage: no } \\
\text { explicit stage defined. } \\
\text { * gender: no explicit focus } \\
\text { reported. }\end{array}$ \\
\hline
\end{tabular}




\begin{tabular}{|c|c|c|c|c|c|c|}
\hline & $\begin{array}{l}\text { * Embase } \\
\text { * The Cochrane } \\
\text { Library; all databases } \\
\text { * Dates of coverage: } \\
\text { 1990- June 24, } 2012 \\
\text { * Reference lists from } \\
\text { eligible articles and } \\
\text { recent reviews. }\end{array}$ & & $\begin{array}{l}\text { interventions } \\
\text {-reliability of paper vs mobile phone-based } \\
\text { assessments; Evaluations of applications tested } \\
\text { exclusively on laptops, netbooks or tablet computers. }\end{array}$ & & & \\
\hline $\begin{array}{l}\text { Griffiths et al. } \\
2009 \\
\text { Australia [15] } \\
3\end{array}$ & $\begin{array}{l}\text { * PubMed } \\
\text { * PsycINFO } \\
\text { * The Cochrane } \\
\text { library } \\
\text { * Dates of coverage: } \\
\text { period before Aug. } \\
2007 \\
\text { * Dates of searches: } \\
\text { May } 2005 \text { and July } \\
2007 \\
\text { * Reference lists of } \\
\text { included studies. }\end{array}$ & $\begin{array}{l}\text { To provide } \\
\text { comprehensive } \\
\text { overview of effects of } \\
\text { Internet Support } \\
\text { Groups on depressive } \\
\text { symptoms }\end{array}$ & $\begin{array}{l}\text { Inclusion criteria stage 1: Peer- to-peer interaction; At } \\
\text { least one of following: online/electronic support } \\
\text { groups, online/electronic social or peer support, } \\
\text { online/computer-based communication or interaction, } \\
\text { collaborative virtual environments or interventions; } \\
\text { Support "group” was health/psychology related or } \\
\text { article measured health/psychology related outcome } \\
\text { in relation to a support group. } \\
\text { Inclusion criteria stage 2: Study employed online } \\
\text { peer-to-peer support group; Study incorporated either } \\
\text { a depression outcome or involved unipolar depression } \\
\text { Internet Support Group. } \\
\text { Inclusion criteria stage 3: Study reported either } \\
\text { quantitative or qualitative empirical data. } \\
\text { Exclusion criteria stage 4: No depression outcome or } \\
\text { study did not concern Internet Support Group } \\
\text { exclusively devoted to depression; Duplicates after } \\
\text { second search; Non-English language. }\end{array}$ & $\begin{array}{l}\text { * Possible role of different } \\
\text { characteristics and quality } \\
\text { explored by comparing samples } \\
\text { which reported to have yielded } \\
\text { positive statistically significant } \\
\text { results with those that did not: } \\
\text { Series of Fisher exact tests and } \\
\text { Mann-Whitney tests. Data } \\
\text { analyzed at comparison rather } \\
\text { than study level. } \\
\text { * For descriptive purposes, } \\
\text { where possible, Cohen's d } \\
\text { standardized effect sizes } \\
\text { calculated. } \\
\text { * Uncontrolled studies: pre- } \\
\text { post standardized effect size } \\
\text { calculated from mean pre-test } \\
\text { and post-test scores and } \\
\text { standard deviations. } \\
\text { * Controlled studies, study } \\
\text { effect size: difference between } \\
\text { pre-post effect size control } \\
\text { group and pre-post effect size } \\
\text { intervention group calculated. } \\
\text { * When only t test value for } \\
\text { dependent (or equivalent) } \\
\text { samples available: no effect } \\
\text { size estimated. } \\
\text { * When only baseline adjusted } \\
\text { means + baseline adjusted } \\
\text { difference in change available: } \\
\text { no effect sizes calculated. }\end{array}$ & 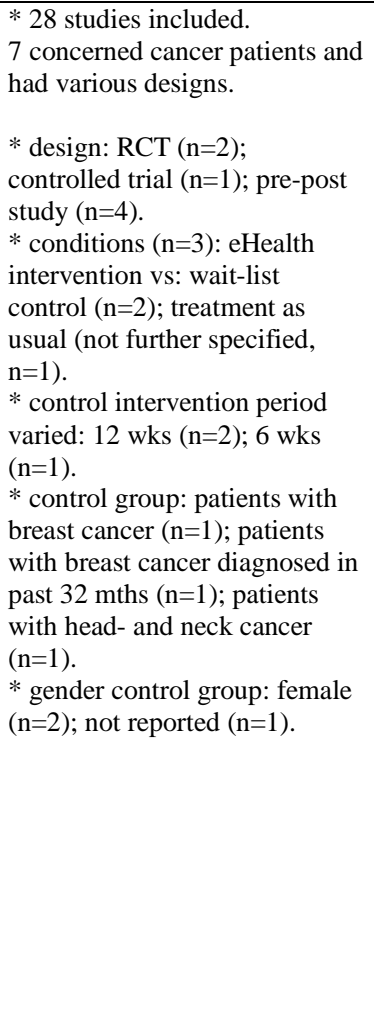 & $\begin{array}{l}\text { * population: people with a } \\
\text { variety of chronic diseases. } \\
7 \text { studies concerned cancer } \\
\text { patients. } \\
\text { * tumor type: breast }(\mathrm{n}=6) ; \\
\text { head or neck-cancer (n=1). } \\
\text { * disease/clinical stage: } \\
\text { - breast cancer: diagnosed past } \\
32 \text { mths ( } \mathrm{n}=1) \\
\text { - head or neck-cancer: post- } \\
\text { surgery (n=1); no report of } \\
\text { stage }(\mathrm{n}=5) \text {. } \\
\text { * gender: only female (n=6); } \\
\text { not reported (n=1). } \\
\text { * other: Inclusion of some rural } \\
\text { residents (n=1); Participants } \\
\text { joined } 1 \text { of } 5 \text { frequently used } \\
\text { bulletin boards }<8 \text { wks } \\
\text { previous to participation in } \\
\text { study (n=1); Participants joined } \\
1 \text { of } 4 \text { frequently used bulletin } \\
\text { boards }<8 \text { wks previous to } \\
\text { participation in study (n=1); } \\
\text { Participants who have } \\
\text { previously posted on Breast } \\
\text { Cancer bulletin board during a } \\
\text { particular } 1 \text {-wk period (n=1); } \\
\text { Financial incentive given to } \\
\text { patients for participation (n=1). }\end{array}$ \\
\hline
\end{tabular}




\begin{tabular}{|c|c|c|c|c|c|c|}
\hline $\begin{array}{l}\text { Gysels } \\
\text { \& } \\
\text { Higginson } \\
2007 \\
\text { UK [16] } \\
4,5\end{array}$ & $\begin{array}{l}\text { * MEDLINE (1966- } \\
\text { wk } 3 \text { of April 2006) } \\
\text { * Embase (1980 - } \\
\text { wk } 18 \text { 2006) } \\
\text { * CINAHL (1982- } \\
\text { wk } 3 \text { of April 2006) } \\
\text { * Cochrane Database } \\
\text { of Systematic Reviews } \\
\text { * Cochrane Central } \\
\text { Register of Controlled } \\
\text { Trials } \\
\text { * Dates of coverage: } \\
\text { wk } 3 \text { of April 2006 } \\
\text { * Reference lists of } \\
\text { included studies. } \\
\text { * Expert panel's advice } \\
\text { on recently published } \\
\text { articles or ongoing } \\
\text { research. }\end{array}$ & $\begin{array}{l}\text { To assess benefits of } \\
\text { interactive multimedia } \\
\text { technologies and } \\
\text { videotapes for patient } \\
\text { education }\end{array}$ & $\begin{array}{l}\text { Inclusion criteria: RCTs; Patient education to improve } \\
\text { knowledge, satisfaction, decision making, treatment } \\
\text { choice or care management; Videotape or computer } \\
\text { programs; Cancer care; Only diagnostic screening } \\
\text { procedures. } \\
\text { Exclusion criteria: Studies involving hypothetical } \\
\text { choices, informed consent to take part in clinical trial, } \\
\text { decisions regarding preventive screening or public } \\
\text { health measures; Interventions intended for other } \\
\text { purposes than treatment decision making and } \\
\text { informed consent; Interventions experimenting with } \\
\text { Internet; Focus on children; Non-intervention studies. }\end{array}$ & $\begin{array}{l}\text { * Meta-analysis: when } \\
\text { sufficient comparable outcome } \\
\text { data } \geq 2 \text { studies; heterogeneity } \\
\text { testing using the } \chi 2 \text { test; } \\
\text { random-effects model applied. } \\
\text { * Continuous data summarized } \\
\text { as weighted mean differences } \\
\text { with } 95 \% \text { confidence intervals. } \\
\text { * Dichotomous data } \\
\text { summarized as odds ratios with } \\
95 \% \text { confidence intervals. } \\
\text { * Analysis of continuous + } \\
\text { dichotomous data altogether: } \\
\text { Effect sizes for all outcomes } \\
\text { calculated by dividing } \\
\text { estimated mean difference or } \\
\text { difference in proportions, by } \\
\text { sample standard deviation. }\end{array}$ & $\begin{array}{l}\text { * } 9 \text { studies included. } 6 \\
\text { concerned effects of eHealth } \\
\text { interventions. } \\
\text { * design: RCT. } \\
\text { * conditions: eHealth } \\
\text { intervention vs: reading } \\
\text { material: Susan Love's Breast } \\
\text { Book (n=1); usual care: } \\
\text { standard information and (face- } \\
\text { to-face) care from } \\
\text { multidisciplinary team }(\mathrm{n}=1) ; \\
\text { standard education }(\mathrm{n}=1) ; \\
\text { brochure (n=1); face-to-face } \\
\text { medical consultation }(\mathrm{n}=1) ; \\
\text { information booklets }(\mathrm{n}=1) \text {. } \\
\text { * gender control group: female } \\
(\mathrm{n}=4) ; \text { mixed }(\mathrm{n}=2) .\end{array}$ & $\begin{array}{l}\text { * population: patients }(\mathrm{n}=6) \\
\text { * tumor type: breast }(\mathrm{n}=4) ; \\
\text { various ( } \mathrm{n}=1) \text {; referred for } \\
\text { colonoscopy; not specified } \\
(\mathrm{n}=1) \text {. } \\
\text { * disease/clinical stage: } \\
\text { - breast cancer: newly } \\
\text { diagnosed ( } \mathrm{n}=1) \text {; recently } \\
\text { diagnosed }(\mathrm{n}=1) \text {; stage } \mathrm{I} / \mathrm{II} \\
(\mathrm{n}=1) \text {; histologically confirmed } \\
\text { axillary node-negative breast } \\
\text { cancer and primary surgery at } \\
\text { first consultation for adjuvant } \\
\text { systemic therapy }(\mathrm{n}=1) . \\
\text { - various types: started radical } \\
\text { radiotherapy (n=1). } \\
\text { - referred for colonoscopy: } \\
\text { undergoing colonoscopy }(\mathrm{n}=1) . \\
\text { * age: <60 years }(\mathrm{n}=1) \text {; not } \\
\text { reported }(\mathrm{n}=5) . \\
\text { * gender: female }(\mathrm{n}=4) \text {; not } \\
\text { reported }(\mathrm{n}=2) .\end{array}$ \\
\hline $\begin{array}{l}\text { Hoey et al. } \\
2008 \\
\text { Australia [17] } \\
4,5\end{array}$ & $\begin{array}{l}\text { * CINAHL } \\
\text { * MEDLINE } \\
\text { * PsycINFO } \\
\text { * Dates of coverage: } \\
\text { (1980-April 2007) } \\
\text { * Reference lists of } \\
\text { included studies. } \\
\text { * Key researchers } \\
\text { were contacted for } \\
\text { identification } \\
\text { additional } \\
\text { publications. }\end{array}$ & $\begin{array}{l}\text { To identify different } \\
\text { peer support models } \\
\text { and examine research } \\
\text { assessing their } \\
\text { effectiveness }\end{array}$ & $\begin{array}{l}\text { Inclusion criteria: English language; Description of } \\
\text { specific program where peers provided direct support } \\
\text { to people with cancer; Peer who has been diagnosed } \\
\text { and/or treated for cancer; Primary program purpose: } \\
\text { to provide support to cancer patients. } \\
\text { Exclusion criteria: Not specific peer-support program; } \\
\text { Focus on children or adolescents; Educational or } \\
\text { therapeutic course run by professionals (incl. } \\
\text { supportive expressive therapy); No primarily focus on } \\
\text { peer support; Peer support from someone other than } \\
\text { person with cancer; No sufficiently detailed program } \\
\text { description; Not possible to determine how peer } \\
\text { provided support; Not possible to determine if peer } \\
\text { support provider had experienced cancer; Editorial or } \\
\text { letter concerning program; First-person account of an } \\
\text { experience. }\end{array}$ & $\begin{array}{l}\text { * Selected papers classified } \\
\text { into one of following pre- } \\
\text { determined categories: } \\
\text { - non-research theoretical or } \\
\text { service usage; papers } \\
\text { describing proposed model or } \\
\text { specific program+papers no } \\
\text { data containing apart from } \\
\text { service usage data } \\
\text { - one group descriptive; } \\
\text { describing program with data } \\
\text { collection, one group only and } \\
\text { no experimental design) } \\
\text { - non-randomized comparative } \\
\text { studies } \\
\text { - randomized controlled trials. }\end{array}$ & $\begin{array}{l}\text { *44 studies included. } 7 \\
\text { concerned effects of eHealth } \\
\text { interventions. } \\
\text { * designs: qualitative ( } \mathrm{n}=4) \text { :- } \\
\text { telephone interviews }(\mathrm{n}=2) \\
\text { - face-to-face + online } \\
\text { interviews ( } \mathrm{n}=1 \text { ) } \\
\text { - content analysis posted } \\
\text { messages ( } \mathrm{n}=1) \text {; RCTs }(\mathrm{n}=2) \text {. } \\
\text { * conditions: eHealth } \\
\text { intervention vs: providing } \\
\text { information in form of booklet } \\
\text { concerning breast cancer }(\mathrm{n}=1) \text {; } \\
\text { wait-list control }(\mathrm{n}=1) \text {. } \\
\text { *control group: not explicitly } \\
\text { reported ( } \mathrm{n}=2 \text { ). }\end{array}$ & $\begin{array}{l}* \text { * population: patients }(\mathrm{n}=7) \\
\text { * tumor type: breast }(\mathrm{n}=7) \\
\text { * gender: female }(\mathrm{n}=7)\end{array}$ \\
\hline
\end{tabular}




\begin{tabular}{|c|c|c|c|c|c|c|}
\hline $\begin{array}{l}\text { Hong et al. } \\
2012 \\
\text { USA [18] } \\
3\end{array}$ & $\begin{array}{l}\text { * PsycINFO } \\
\text { * ERIC } \\
\text { * MEDLINE via } \\
\text { PubMed } \\
\text { * Dates of coverage: ? } \\
\text { * Reference lists of } \\
\text { included studies. }\end{array}$ & $\begin{array}{l}\text { To systematically } \\
\text { review existing studies } \\
\text { on outcomes } \\
\text { concerning online } \\
\text { support or resources }\end{array}$ & $\begin{array}{l}\text { Inclusion criteria: Empirical data (either qualitative or } \\
\text { quantitative methods) on use online cancer } \\
\text { support/resources; Reported outcome measures; } \\
\text { Focus on adult cancer survivors; English language; } \\
\text { Peer-reviewed articles published before July 2010. } \\
\text { Exclusion criteria: Descriptive studies which did not } \\
\text { report outcomes; No focus on cancer survivors; } \\
\text { Focus on computer-based resources (without access } \\
\text { to Internet); review studies; theoretical articles. }\end{array}$ & Not reported & $\begin{array}{l}\text { * } 24 \text { studies included. } \\
\text { * design: cross-sectional } \\
\text { survey/interview (n=15): focus } \\
\text { groups, in-depth interviews, } \\
\text { ethnographic case studies, pre- } \\
\text { post studies ( } \mathrm{n}=5 \text { ); } \mathrm{RCTs}(\mathrm{n}=4) \text {. } \\
\text { *conditions: online educational } \\
\text { control condition (n=1); not } \\
\text { reported ( } \mathrm{n}=3 \text { ). } \\
\text { * control group: patients ( } \mathrm{n}=4 \text { ) } \\
\text { * gender control group: female } \\
\text { (n=3); not reported ( } \mathrm{n}=1) .\end{array}$ & 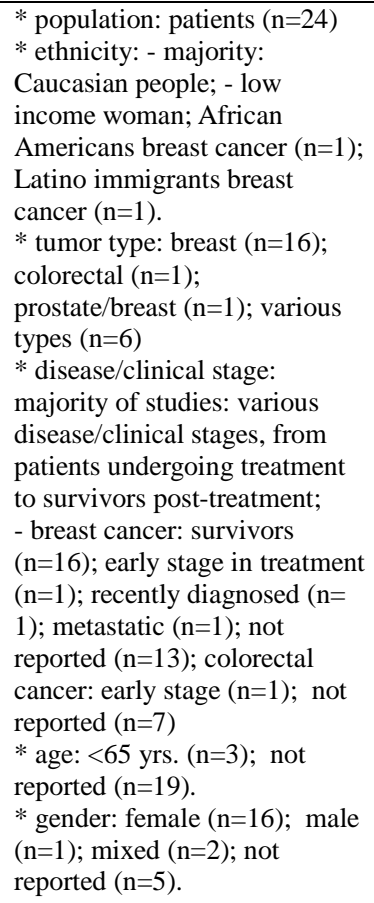 \\
\hline $\begin{array}{l}\text { Johansen et al. } \\
2012 \\
\text { Norway [19] } \\
3,5\end{array}$ & $\begin{array}{l}\text { Via Ovid: } \\
\text { * MEDLINE } \\
\text { * Embase } \\
\text { * PsycINFO } \\
\text { * Cochrane Central } \\
\text { Register of Controlled } \\
\text { Trials } \\
\text { * IEEE Xplore } \\
\text { * Dates of coverage: } \\
\text { (1990-November } \\
\text { 2011) } \\
\text { * Date of searches: } \\
\text { May 2011 and 2 } \\
\text { updates in October and } \\
\text { November 2011 }\end{array}$ & $\begin{array}{l}\text { To create } \\
\text { comprehensive an } \\
\text { overview of } \\
\text { knowledge focusing } \\
\text { on electronic } \\
\text { communication } \\
\text { between patient and } \\
\text { provider to improve } \\
\text { health care service } \\
\text { quality, and to clarify } \\
\text { what has been } \\
\text { investigated so far } \\
\text { regarding different } \\
\text { patient groups, health } \\
\text { service innovations, } \\
\text { research targets and } \\
\text { relevant electronic } \\
\text { symptom reporting }\end{array}$ & $\begin{array}{l}\text { Inclusion criteria: original study; patients or parents; } \\
\text { Electronically reported symptoms or health } \\
\text { information to clinical health care personnel or } \\
\text { system, where receiver processed and interpreted data } \\
\text { and provided feedback; Reported information had to } \\
\text { concern symptoms and health status at time of } \\
\text { reporting or during preceding few days; RCT } \\
\text { comparing electronic symptom reporting vs control } \\
\text { where symptom or health information was not } \\
\text { received by health care professionals or systems. } \\
\text { Exclusion criteria: Retrospective questionnaires, } \\
\text { prevalence surveys, general screening on Internet, } \\
\text { tests of medications; Electronic communication } \\
\text { requiring simultaneous presence of patient and health } \\
\text { care personnel; automatic biometric measurements; } \\
\text { voice diary. }\end{array}$ & $\begin{array}{l}* \text { Qualitative content analysis } \\
\text { of data } \\
\text { * Qualitative analysis of study } \\
\text { as whole } \\
\text { * Quantitative analysis applied: } \\
\text { not reported }\end{array}$ & $\begin{array}{l}\text { * } 29 \text { studies included. } 6 \\
\text { concerned cancer patients. } \\
\text { * design: RCT } \\
\text { * conditions: eHealth } \\
\text { intervention vs: electronic Self- } \\
\text { Report Assessment-Cancer: } \\
\text { color graphical summary of } \\
\text { participant’s self-reported } \\
\text { symptoms and quality of life } \\
\text { issues with predetermined } \\
\text { thresholds flagged. No } \\
\text { summary handed to clinician } \\
\text { (n=1); Touch-screen survey } \\
\text { filled out before oncologist } \\
\text { visit. Computer scored answers. } \\
\text { No results made available to } \\
\text { oncologist (n=1); All patients } \\
\text { scheduled for outpatient visit } \\
\text { used system on tablet computer }\end{array}$ & 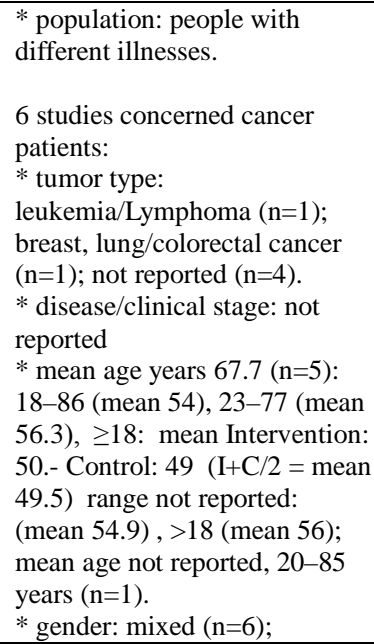 \\
\hline
\end{tabular}




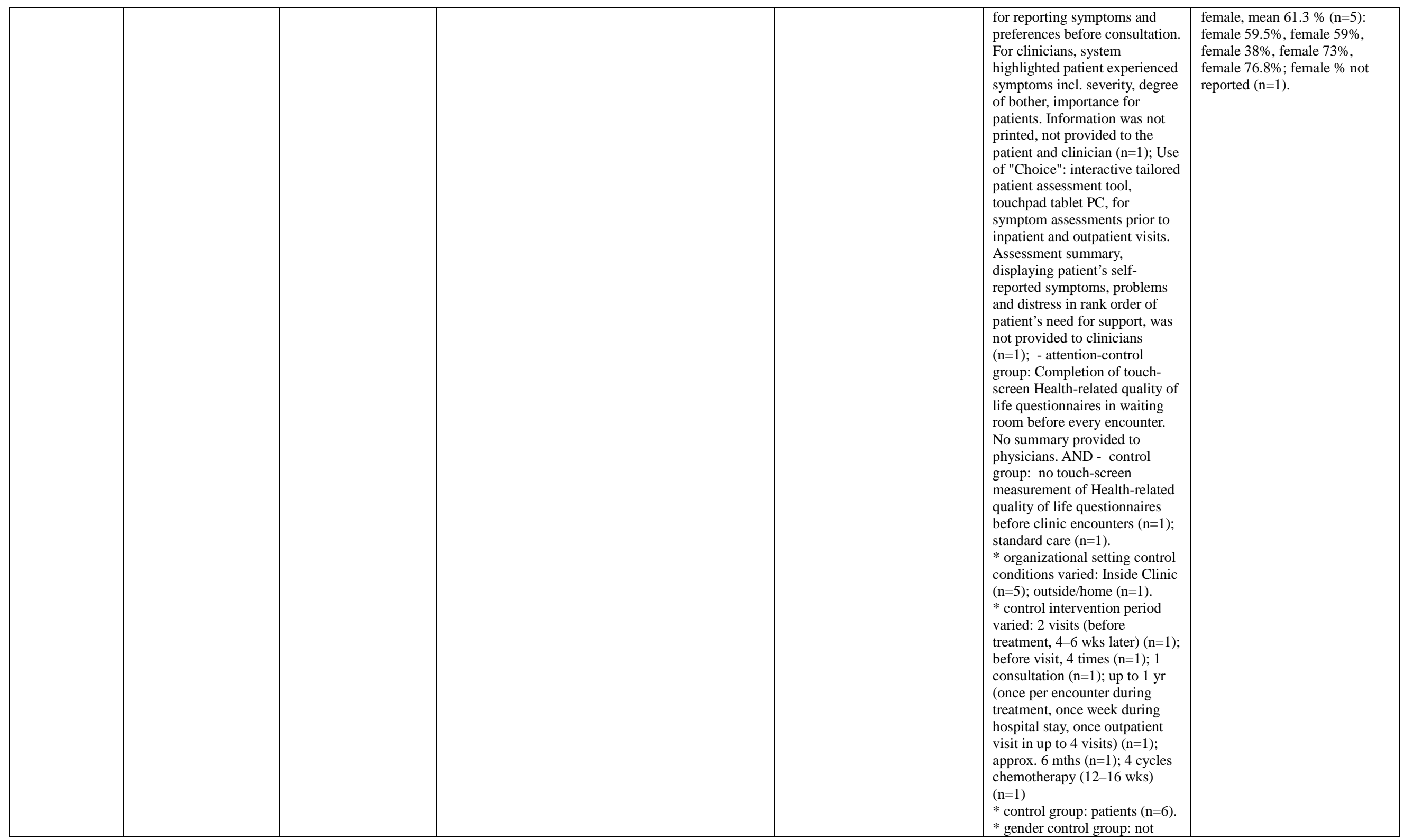




\begin{tabular}{|c|c|c|c|c|c|c|}
\hline & & & & & reported $(\mathrm{n}=6)$. & \\
\hline $\begin{array}{l}\text { Ryhanen et al. } \\
2010 \\
\text { Finland [20] } \\
3,5\end{array}$ & $\begin{array}{l}\text { * Cochrane Database } \\
\text { of Systematic Reviews } \\
\text { (Issue 4, 2008) } \\
\text { * CINAHL (1982- } \\
\text { 2008) } \\
\text { * MEDLINE (1950- } \\
\text { 2008) } \\
\text { * PsycINFO (1995- } \\
\text { 2008) } \\
\text { * ERIC (1966-2008) } \\
\text { * ScienceDirect } \\
\text { (1994-2008) } \\
\text { * Social Science } \\
\text { Citation Index (1956- } \\
\text { 2008) } \\
\text { * Education Research } \\
\text { Complete (1990- } \\
\text { 2008) }\end{array}$ & $\begin{array}{l}\text { To provide a } \\
\text { description of internet } \\
\text { and interactive } \\
\text { computer-based } \\
\text { patient educational } \\
\text { programs and analyze } \\
\text { their effectiveness }\end{array}$ & $\begin{array}{l}\text { Inclusion criteria: RCTs, clinical trials and quasi } \\
\text { experimental studies; English language; Internet- } \\
\text { based patient education as use of World Wide Web or } \\
\text { with modem connections to central server for } \\
\text { communication for patient education; Use of } \\
\text { computer with CD-ROMs. } \\
\text { Exclusion criteria: Use of computer for generating } \\
\text { written patient education materials and e-mails; Use } \\
\text { of computer by health care professionals; Solely } \\
\text { examining support groups' efficiency; Focus solely } \\
\text { on breast cancer screening. }\end{array}$ & Not reported & 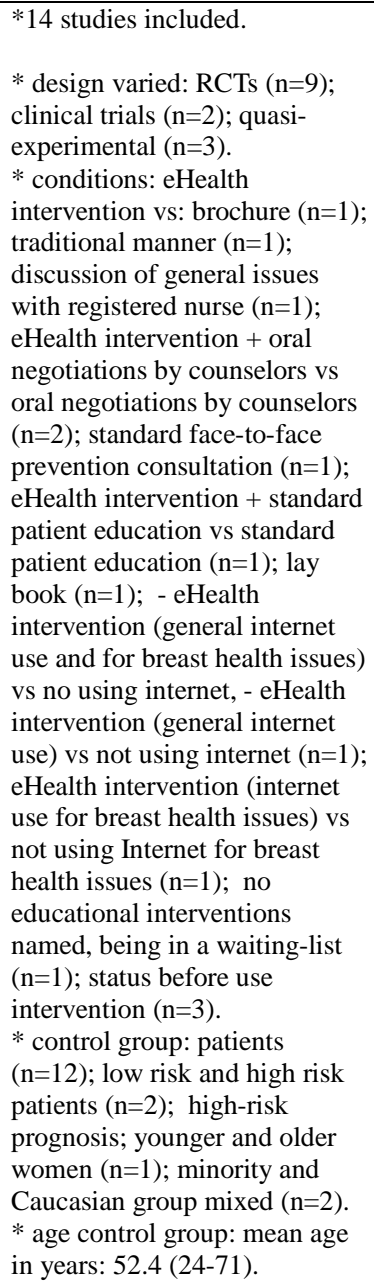 & 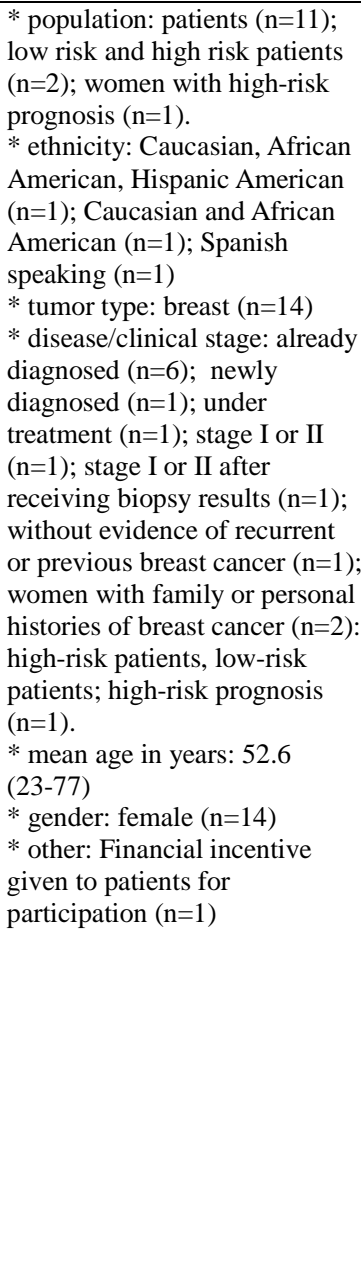 \\
\hline $\begin{array}{l}\text { Salonen et al. } \\
2014 \\
\text { Finland [ 21] } \\
3,5\end{array}$ & $\begin{array}{l}\text { * Ovid MEDLINE } \\
\text { (1948-2011) } \\
\text { * Ovid Nursing } \\
\text { Database (1948-2011) } \\
\text { * Cochrane (1991- } \\
\text { 2011) } \\
\text { * CINAHL (1996- }\end{array}$ & $\begin{array}{l}\text { To evaluate benefits of } \\
\text { best available evidence } \\
\text { for Internet use or use } \\
\text { of computer-based } \\
\text { programs for cancer- } \\
\text { related information, } \\
\text { emotional or spiritual }\end{array}$ & $\begin{array}{l}\text { Inclusion criteria: quantitative or qualitative design; } \\
\text { prostate cancer patients; English language; Use of } \\
\text { computer/Internet/websites with CD-ROMs, when } \\
\text { programs were interactive; Outcome was reported } \\
\text { qualitatively or quantitatively. } \\
\text { Exclusion criteria: Dissemination of prostate cancer }\end{array}$ & Not reported & $\begin{array}{l}\text { *18 studies included. } 9 \\
\text { concerned effects of eHealth } \\
\text { interventions. } \\
\text { * designs: } \mathrm{RCTs}(\mathrm{n}=2) \text {; pre- } \\
\text { post-quasi-experimental }(\mathrm{n}=2) ; \\
\text { quasi-experimental }(\mathrm{n}=1) \text {; pre- }\end{array}$ & $\begin{array}{l}\text { * population: patients ( }=8) ; \\
\text { patients and spouses/partners } \\
\text { (n=1) } \\
\text { * ethnicity: Caucasian (Asian } \\
\text { people possibly included); } \\
\text { English speaking (French } \\
\text { speaking people possibly }\end{array}$ \\
\hline
\end{tabular}




\begin{tabular}{|c|c|c|c|c|c|c|}
\hline & $\begin{array}{l}\text { 2011) } \\
\text { * PsycINFO (1997- } \\
\text { 2011). } \\
\text { * Reference lists of } \\
\text { included studies. }\end{array}$ & support & $\begin{array}{l}\text { risks and screening information; Examination of } \\
\text { information resources in prostate cancer treatment; } \\
\text { Descriptive studies not reporting outcomes; review } \\
\text { studies or theoretical articles. }\end{array}$ & & $\begin{array}{l}\text { post studies }(\mathrm{n}=2) \text {; qualitative } \\
\text { studies }(\mathrm{n}=2) \text { - } \text { face-to-face } \\
\text { interview }(\mathrm{n}=1), \text { - in-depth } \\
\text { interviews }(\mathrm{n}=1) \text {. } \\
\text { * conditions: eHealth } \\
\text { intervention vs standard care } \\
\text { (not further specified, } \mathrm{n}=1) \text {; } \\
\text { not reported }(\mathrm{n}=4) \text {. } \\
\text { * control group: not explicitly } \\
\text { reported ( } \mathrm{n}=5) \text {. }\end{array}$ & $\begin{array}{l}\text { included). } \\
\text { * tumor type: (localized) } \\
\text { prostate cancer }(\mathrm{n}=6) ; \text { prostate } \\
\text { cancer and breast cancer }(\mathrm{n}=3) \text {. } \\
\text { * disease/clinical stage: often } \\
\text { recently diagnosed. } \\
\text { * mean age years } 64.1(\mathrm{n}=6) \text { : } \\
\text { 62.4, } 62.2,65.7,66.7,62.3 \text {, } \\
\text { mean intervention: } 62.3 \text { mean } \\
\text { control: } 67.8(\mathrm{I}+\mathrm{C} / 2=\text { mean } \\
\text { 65.05); age not reported }(\mathrm{n}=3) \text {. } \\
\text { * gender: male }(\mathrm{n}=5) \text {; mixed } \\
(\mathrm{n}=4) \text {. }\end{array}$ \\
\hline $\begin{array}{l}\text { Ventura et al., } \\
2013 \\
\text { Sweden [22] } \\
3\end{array}$ & $\begin{array}{l}\text { * PubMed (1950- } \\
\text { 2012) } \\
\text { * CINAHL (1982- } \\
\text { 2012) } \\
\text { * PsycINFO (1872- } \\
\text { 2012) } \\
\text { * Reference lists of } \\
\text { included studies. }\end{array}$ & $\begin{array}{l}\text { To gather more } \\
\text { knowledge of the } \\
\text { design of supportive } \\
\text { eHealth interventions } \\
\text { and to analyze and } \\
\text { synthesize that } \\
\text { knowledge in a } \\
\text { potential explanatory } \\
\text { model for those } \\
\text { interventions }\end{array}$ & $\begin{array}{l}\text { Inclusion criteria: participants > } 18 \text { years; diagnosed } \\
\text { with cancer; starting/undergoing/completed } \\
\text { treatment; supportive eHealth systems designed and } \\
\text { implemented/facilitated by health professionals; all } \\
\text { interventions using videos, CDs or DVDs; } \\
\text { Interventions constituted educational and/or support } \\
\text { tools. } \\
\text { Exclusion criteria: Tools developed for pre-disease } \\
\text { period; descriptive analyses of health information } \\
\text { websites; Report on development (phase I) or } \\
\text { exclusively on usability, acceptability, feasibility } \\
\text { (phase II). }\end{array}$ & $\begin{array}{l}\text { * Data analysis: ordering, } \\
\text { coding and categorization of } \\
\text { primary studies. } \\
\text { * Results were summarized and } \\
\text { integrated into conclusion } \\
\text { regarding research problem. } \\
\text { * Data analysis led to } \\
\text { identification of patterns, } \\
\text { themes and relationships that } \\
\text { were synthesized in potential } \\
\text { explanatory model }\end{array}$ & $\begin{array}{l}\text { *29 studies included. } \\
\text { * design: } \\
\text { one group studies (n=11); } \\
\text { experimental design ( } \mathrm{n}=18) \text { : } \\
\text { two arms studies (n=13), three } \\
\text { arms studies (n=2), four arms } \\
\text { studies (n=3). } \\
\text { * conditions: not reported } \\
(\mathrm{n}=29) \text {. } \\
\text { * control group: probably } \\
\text { healthy women }(\mathrm{n}=1) ; \text { not } \\
\text { explicitly reported }(\mathrm{n}=28) .\end{array}$ & 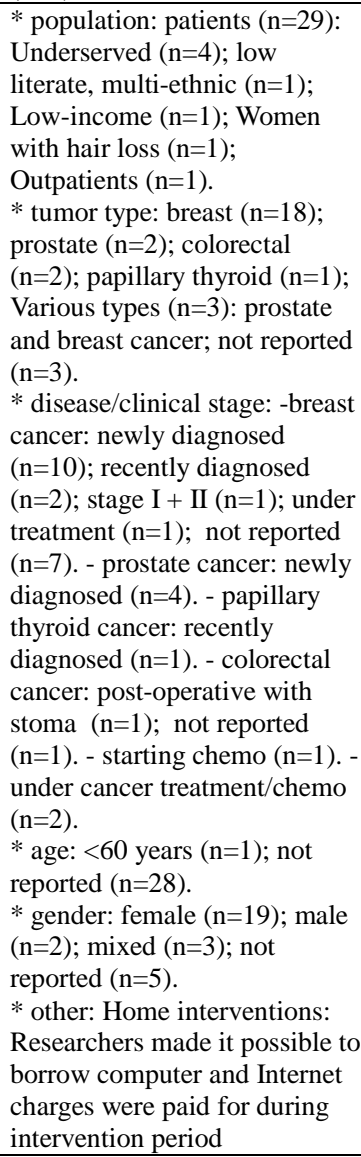 \\
\hline
\end{tabular}



Table S2 Outcomes, Effects, Conclusions

\begin{tabular}{|c|c|c|c|c|}
\hline $\begin{array}{l}\text { Reference and } \\
\text { score } \\
\text { methodological } \\
\text { assessment }\end{array}$ & Time measurements & Outcomes & Results concerning effects of eHealth & Review's conclusions and reflections concerning effects of eHealth on cancer patients \\
\hline $\begin{array}{l}\text { Beatty et al. } \\
2013[13] \\
5\end{array}$ & $\begin{array}{l}\text { * Pre-test and post- } \\
\text { test after } 12 \mathrm{wks}\end{array}$ & $\begin{array}{l}\text { * Distress } \\
* \text { Quality of life } \\
\text { * Wellbeing }\end{array}$ & $\begin{array}{l}\text { Psychological wellbeing } \\
\text { No effects on: } \\
\text { * psychological distress } \\
\text { * emotional wellbeing } \\
\text { Physical wellbeing } \\
\text { No effects } \\
\frac{\text { Quality of life }}{\text { No effects }} \\
\frac{\text { Health status }}{\text { Positive effects on: }} \text { * global perceived health for people with poor baseline levels }\end{array}$ & $\begin{array}{l}\text { Conclusion } \\
\text { * Moderate evidence was found for chronic pain-related distress; however, limited } \\
\text { research conducted among cancer patients currently precludes conclusions from being } \\
\text { drawn. } \\
\text { Reflections } \\
\text { * Conclusions concerning lack of evidence for effects on cancer patients might be } \\
\text { premature given that only one study was conducted. This limits ability to draw } \\
\text { conclusions. } \\
\text { * Waitlist designs are weaker as control participants are less likely to seek constructive } \\
\text { action compared to alternative control-groups, as they anticipate future therapeutic input. } \\
\text { * Tentative evidence was found for online interventions leading to significant } \\
\text { improvements of physical symptom/disease-control in cancer patients. }\end{array}$ \\
\hline $\begin{array}{l}\text { Bender et al. } \\
2013[14] \\
3\end{array}$ & not applicable & $\begin{array}{l}\text { All potentially } \\
\text { relevant } \\
\text { outcomes }\end{array}$ & $\begin{array}{l}\text { No research found } \\
\text { * No studies concerning evaluation of cancer-focused smartphone applications } \\
\text { were found. }\end{array}$ & $\begin{array}{l}\text { Conclusion } \\
\text { * Considerable number of cancer-focused applications available. } \\
\text { * Lack of evidence base in favor of applications, despite mobile devices offering } \\
\text { remarkably low-cost, real-time ways to encourage preventive strategies, monitor } \\
\text { behaviors, symptoms physiological indicators and provide interventions. } \\
\text { * Focus of future efforts should be on improving and consolidating evidence on utility, } \\
\text { safety, effectiveness of mobile cancer applications into a whitelist for public consumption. } \\
\text { Reflections } \\
\text { * Majority targeted breast cancer or cancer in general } \\
\text { * Increasing number available health apps } \\
\text { * Cancer apps on their own have limited potential value in delivering health behavior- } \\
\text { changing interventions. } \\
\text { * Focus raising awareness /provision educational information } \\
\text { Minority od applications combined information provision with skill-building tools } \\
\text { assisting in performance of preventive, detection or self-management behaviors. } \\
\text { * Limited use of smartphone's technical capabilities, e.g. audio recording, self-monitoring } \\
\text { using photos and automated sensing for tracking . Majority uses textual entry or touch } \\
\text { screen completion. } \\
\text { * Limited use of assistance through mobile sensing platforms of smartphones in automated } \\
\text { logging symptoms or health behaviors. } \\
\text { * Effective self-management requires effective communication with + support from } \\
\text { healthcare team. Limited use features facilitating communication with healthcare team. } \\
\text { Restricted to tools identification, prioritizing questions and journaling apps to take notes. } \\
\text { * Limited use of advantage of smartphone's social networking capabilities. } \\
\text { * Lack of evidence on effectiveness and description of procedures/data sources is } \\
\text { worrisome. } \\
\text { * Over-representation of breast cancer apps, under-representation of prostate, lung, and } \\
\text { colorectal apps. } \\
\text { * Current lack of synthesis of regulations on development, evaluation, reporting standards } \\
\text { and criteria for selecting health applications. } \\
\text { * Applications potentially cause distress and harm if provided advice is misleading and } \\
\text { unsupervised. }\end{array}$ \\
\hline
\end{tabular}




\begin{tabular}{|c|c|c|c|c|}
\hline $\begin{array}{l}\text { Griffiths et al. } \\
2009 \text { [15] } \\
3\end{array}$ & $\begin{array}{l}\text { Various: } \\
\text { * Baseline, wks } \\
\text { * Baseline, } 16 \text { wks, } \\
20 \text { wks } \\
\text { * "Baseline", } 6 \text { mths } \\
\text { post "baseline” } \\
\text { * Analysis mood; } \\
\text { First online post, Last } \\
\text { online post } \\
\text { * Baseline, } 6 \text { wks, } 3 \\
\text { mths }\end{array}$ & * Depression & $\begin{array}{l}\text { Depression and anxiety } \\
\text { Positive effects on: } \\
\text { * reduction of depressive symptoms (single-component interventions) } \\
\text { No effects on: } \\
\text { * depressive symptoms in baseline adjusted mean at } 12 \text { wks (multi-component } \\
\text { intervention) } \\
\text { * depressive symptoms in baseline adjusted difference at } 6 \text { wks and } 3 \text { mths ( multi- } \\
\text { component intervention) } \\
\text { Psychological wellbeing } \\
\text { * possibly small association between board use and improved mood (single- } \\
\text { component intervention) } \\
\text { Other } \\
\text { * breast cancer Internet Support Groups are more successful than Internet Support } \\
\text { Groups focusing on other diagnoses (Fisher exact test, } \mathrm{P}=.02 \text { ) }\end{array}$ & $\begin{array}{l}\text { Conclusion } \\
\text { * There is a need for high-quality research on effect of Internet Support Groups on } \\
\text { depression outcomes. } \\
\text { Reflections } \\
\text { * Baseline measures of depression were not predictive dropout } \\
\text { * Predictors for non-adherence: poorer coping anxiety, more fatalistic, less pain } \\
\text { interference in life, less perceived change in relationships/personal strength } \\
\text { * No baseline differences in demographics, clinical characteristics, depression severity, } \\
\text { posttraumatic growth/psychosocial well-being between completers and non-completers. } \\
\text { * There is a paucity of high-quality studies: Minority consisted of controlled studies. } \\
\text { * Results yielded about breast cancer Internet Support Groups being more successful than } \\
\text { other types of Internet Support Groups, requires further investigation. Women with breast } \\
\text { cancer are known for increased risk of depression. If found effective, breast cancer } \\
\text { Internet Support Groups could provide an important mental health self-care and prevention } \\
\text { tool for women with breast cancer. However, status of current results are unclear given } \\
\text { majority of findings being derived from one research group and underlying studies being } \\
\text { typically of low quality. }\end{array}$ \\
\hline $\begin{array}{l}\text { Gysels } \\
\& \\
\text { Higginson } \\
2007 \text { [16] } \\
4,5\end{array}$ & $\begin{array}{l}\text { Various: } \\
\text { * Pre- test + } 2 \text { post- } \\
\text { test surveys (2+5 } \\
\text { mths follow-up) } \\
\text { * In some instances, } \\
\text { time measurement } \\
\text { was not reported }\end{array}$ & $\begin{array}{l}\text { * Knowledge } \\
\text { * Satisfaction } \\
\text { * Decision } \\
\text { making } \\
\text { * Treatment } \\
\text { choice } \\
\text { * Care } \\
\text { management }\end{array}$ & $\begin{array}{l}\text { Knowledge and information } \\
\text { Positive effects on: } \\
\text { * information competence after } 2 \text { mths at breast cancer patients } \\
\text { * information competence after } 5 \text { mths at breast cancer patients } \\
\text { * information competence for women with breast cancer and of color, uninsured or } \\
\text { those with less education } \\
\text { * knowledge at breast cancer patients after receiving information about breast } \\
\text { cancer treatment } \\
\text { * knowledge at patients who started radical radiotherapy after receiving } \\
\text { personalized information } \\
\text { * overall information comprehension by colonoscopy patients } \\
\text { Support } \\
\text { Positive effects on: } \\
\text { * social support after } 5 \text { mths at breast cancer patients } \\
\text { less education } \\
\text { Decision making } \\
\text { Positive effects on: } \\
\text { *satisfaction with decision making concerning treatment by breast cancer patients } \\
\text { No effects on: } \\
\text { * decision making concerning treatment by breast cancer patients } \\
\text { * satisfaction with treatment decision of breast cancer patients } \\
\text { Healthcare participation and patient involvement } \\
\text { Positive effects on: } \\
\text { * healthcare participation after } 2 \text { mths at breast cancer patients } \\
\text { * healthcare participation for women with breast cancer and of color, uninsured or } \\
\text { those with less education } \\
\text { No effects on: } \\
\text { * healthcare participation by breast cancer patients, after } 5 \text { mths } \\
\text { * patient involvement in consultations for choosing breast cancer treatment }\end{array}$ & $\begin{array}{l}\text { Conclusion } \\
\text { * Claims of reprioritizing patient education as essential element of patients' management } \\
\text { requires evaluation of interventions at different patient groups and in variety of } \\
\text { circumstances. } \\
\text { * Educational technology as effective and, in most outcomes, superior to traditional } \\
\text { methods. They achieved knowledge improvement. } \\
\text { * The interventions did not increase anxiety, and in two interventions, lower levels of } \\
\text { anxiety were reported. } \\
\text { * Computer interventions have a variable impact on patient involvement in decision } \\
\text { making. } \\
\text { * Inconsistencies are due to diversity in interventions undertaken. } \\
\text { * Included studies present only preliminary evaluations. } \\
\text { * Various ways of delivering interventions may affect patient responses and thus the extent } \\
\text { of personal communication with health professional are one of factors affecting patient } \\
\text { responses. } \\
\text { Reflections } \\
\text { * Studies are heterogeneous in design, instruments tested, content provided, populations } \\
\text { examined, outcomes measured and results obtained. Therefore it is difficult to give general } \\
\text { answers regarding effective use of the interventions. } \\
\text { * Various ways of delivering interventions may affect patient responses: some } \\
\text { interventions were administered with assistance of a health professional during } \\
\text { consultation. Advantage: Professional can probe somebody's information requirements, } \\
\text { thoughts, mood which a machine is not able to do. Disadvantage: focus on medical } \\
\text { encounter and danger that complexity of decision-making process may be overlooked. } \\
\text { * Pre-consultation devices still directed towards clinical encounter. However, it allows } \\
\text { patients more independence, and better preparation. } \\
\text { * Take-away/ in-home instruments have advantage that they are available when and where } \\
\text { needed. Less focus on specific decisions and recognize information need outside formal } \\
\text { healthcare episodes. }\end{array}$ \\
\hline
\end{tabular}




\begin{tabular}{|c|c|c|c|c|}
\hline & & & $\begin{array}{l}\text { Depression and anxiety } \\
\text { Positive effects on: } \\
\text { * reduction of anxiety at breast cancer patients during discussion of diagnosis and } \\
\text { treatment } \\
\text { Negative effects on: } \\
\text { * anxiety level at } 3 \text { mths at patients who started radical radiotherapy, after receiving } \\
\text { general information } \\
\text { No effects on: } \\
\text { * depression scores of breast cancer patients during discussion of diagnosis and } \\
\text { treatment } \\
\text { * anxiety at colonoscopy patients } \\
\text { Quality of life } \\
\text { Positive effects on: } \\
\text { * quality of life for women with breast cancer and of color, uninsured or those with } \\
\text { less education } \\
\text { Health status } \\
\text { Positive effects on: } \\
\text { * mental health score of breast cancer patients suggesting improvement of health } \\
\text { status }\end{array}$ & \\
\hline $\begin{array}{l}\text { Hoey et al. } \\
2008 \text { [17] } \\
4,5\end{array}$ & $\begin{array}{l}\text { Various: } \\
* 6 \text { mths post, } 1 \text { yr } \\
\text { following } \\
* 4 \text { mths post, } 8 \text { mths } \\
\text { period } \\
\text { * Baseline, } 16 \text { wks, } 20 \\
\text { wks } \\
\text { * } 3 \text { mth period } \\
\text { (monitoring), post-test } \\
\text { (Scale) } \\
\text { * Baseline, 2, } 5 \text { mths } \\
\text { post-test } \\
\text { *Baseline, } 12 \text { wks } \\
\text { post-test }\end{array}$ & $\begin{array}{l}\text { All potentially } \\
\text { relevant } \\
\text { outcomes }\end{array}$ & $\begin{array}{l}\text { Support } \\
\text { Positive effects on: } \\
\text { * increase informational and social support post intervention } \\
\text { Healthcare participation and patient involvement } \\
\text { Positive effects on: } \\
\text { * increase in healthcare participation at } 2 \text { mths } \\
\text { Depression and anxiety } \\
\text { Positive effects on: } \\
\text { * reduction in depression } \\
\text { * reduction in anxiety } \\
\text { * reduction in fear } \\
\text { Psychological wellbeing } \\
\text { Positive effects on: } \\
\text { * increase in experience of positive changes } \\
\text { Negative effects on: } \\
\text { * increase in emotional suppression } \\
\text { Physical wellbeing } \\
\text { Positive effects on: } \\
\text { * reduction in reaction to pain } \\
\text { Quality of life } \\
\text { No effects } \\
\text { Empowerment and coping } \\
\text { Positive effects on: } \\
\text { 3. participation empowered women through: 1. knowledge, 2. sharing experiences, } \\
\text { 3. new social world, } 4 \text {. social intimacy. }\end{array}$ & $\begin{array}{l}\text { Conclusion: } \\
\text { Overall conclusion concerns peer support programs in general: } \\
\text { * Very little research has specifically explored effectiveness of peer support programs } \\
\text { improving psychological outcomes for cancer patients other than breast cancer patients. } \\
\text { Therefore, it may not be appropriate to generalize findings to other cancer populations. } \\
\text { * Possible that peer support programs are less likely to impact adjustment and quality of } \\
\text { life of breast cancer patients, while an abundance of support is already available for this } \\
\text { patient group. } \\
\text { * Perhaps new, innovative peer-support programs might be beneficial for other cancer } \\
\text { patient groups, particularly those for whom a great deal of support is not available. } \\
\text { * Some of mentioned methodological limitations compromise confidence in findings. } \\
\text { * RCTs with sufficient statistical power for determining small-moderate effect sizes are } \\
\text { particularly lacking. } \\
\text { * Given limited level } 1 \text { evidence on efficacy of peer-support programs, further research is } \\
\text { needed determining whether peer support actually assists cancer patients in adjusting to } \\
\text { diagnosis. } \\
\text { * Review suggests priority should be given to group Internet peer-support programs, when } \\
\text { considering ways of offering peer support. } \\
\text { Reflections } \\
\text { * It is not possible to determine whether psychosocial benefits are related to group Internet } \\
\text { format or to some other factor. } \\
\text { * Some peer support programs tested in the RCTs went for a longer time-period than other } \\
\text {. An extended period of time may be required to develop relationships and build sufficient } \\
\text { rapport to enable people to gain psychosocial benefits from peer support. } \\
\text { * RCTs did not find significant effects on quality of life and coping. This might be result } \\
\text { of wide range of outcomes used. Some outcomes are possibly not suitable assessing } \\
\text { effectiveness of peer support. } \\
\text { * No RCTs screened patients' psychological adjustment/motivation seeking support prior } \\
\text { program. Recruiting people with low levels of psychological distress or who are not open } \\
\text { to receiving support, possibly limits potential psychosocial improvements and impact on } \\
\text { treatment effect sizes. }\end{array}$ \\
\hline
\end{tabular}




\begin{tabular}{|c|c|c|c|c|}
\hline & & & 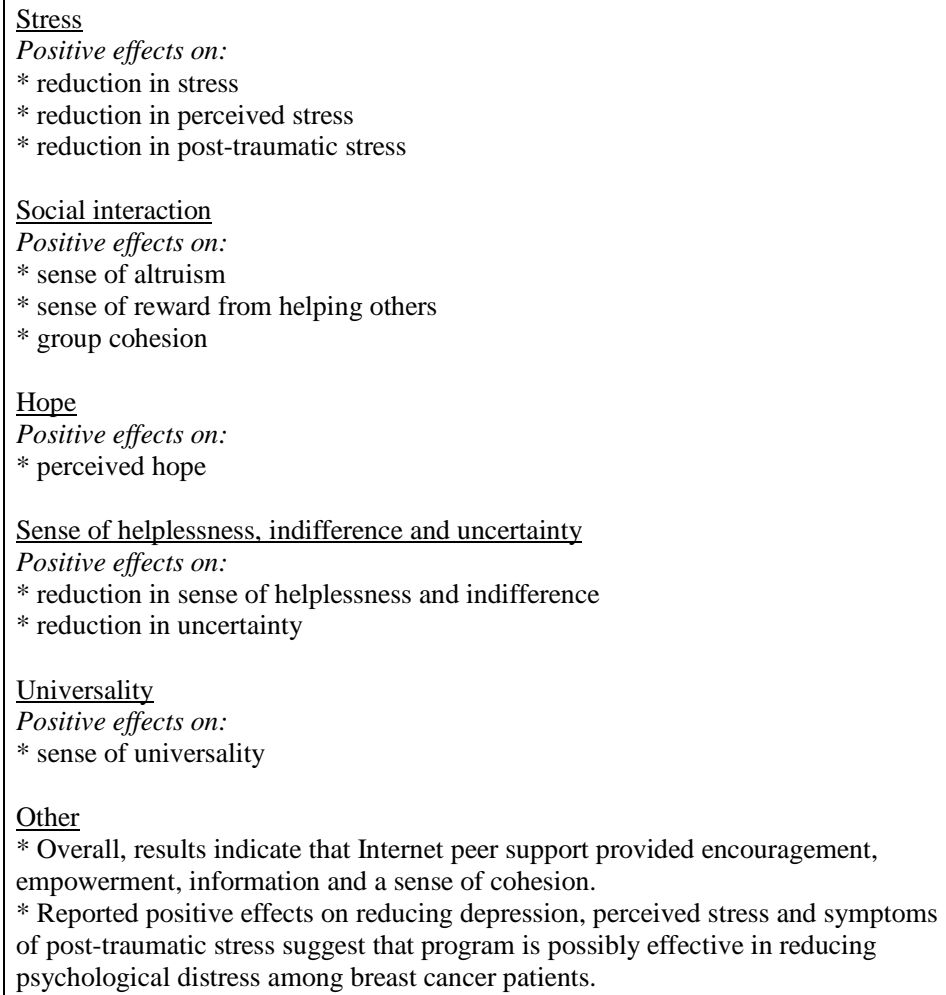 & \\
\hline $\begin{array}{l}\text { Hong et al. } \\
2012 \text { [18] } \\
3\end{array}$ & $\begin{array}{l}\text { Various: } \\
\text { * Pre-test, post-test, 2- } \\
5 \text { mths follow-up } \\
\text { * Pre-test, post -test, } \\
1 \text { mth } \\
\text { * } 12 \text { wks follow-up } \\
\text { * } 12 \text { wks follow-up, } \\
12 \text { mths } \\
\text { * Pre-test, post-test, } 6 \\
\text { mths } \\
\text { * } 1,6,12 \text { mths } \\
\text { follow-up } \\
\text { * } 4 \text { mths, } 12 \text { mths } \\
\text { *In some instances, } \\
\text { time measurement } \\
\text { was not reported } \\
\text { * follow-up pre-post } \\
\text { studies variation } 1-6 \\
\text { mths. Most } 1-3 \text { mths. }\end{array}$ & \begin{tabular}{|l} 
All potentially \\
relevant \\
outcomes
\end{tabular} & $\begin{array}{l}\text { Knowledge and information } \\
\text { Positive effects on: } \\
\text { * information seeking } \\
\text { * information exchange } \\
\text { * health information competence } \\
\text { No effects on: } \\
\text { * barriers to information } \\
\text { Support } \\
\text { Positive effects on: } \\
\text { * social support } \\
\text { * treatment support } \\
\text { * gdvocacy } \\
\text { greater perceived social support } \\
\text { Healthcare participation and patient involvement } \\
\text { Positive effects on: } \\
\text { * healthcare participation }\end{array}$ & $\begin{array}{l}\text { Conclusion: } \\
\text { * Existing studies show promise for achieving positive effects. } \\
\text { * There is inconclusive evidence partly due to lack of rigorous evaluation studies. } \\
\text { * There is a call for more studies on online cancer support based on more rigorous design } \\
\text { methodology, larger study populations including various cancer survivors and underserved } \\
\text { communities. } \\
\text { Reflections } \\
\text { * Rather limited amount of studies reported outcomes concerning online support for } \\
\text { cancer survivors. } \\
\text { * There is need for more rigorous studies that evaluate outcomes of online cancer support } \\
\text { or resources. } \\
\text { * Future studies need to focus on other cancer survivors and males. } \\
\text { * Generalizing findings to other cancer survivors could be difficult, because of } \\
\text { disproportionate focus on women with breast cancer. } \\
\text { * Few studies focus on underserved communities like minorities or people with low social } \\
\text { economic status. } \\
\text { * Important to assess effects of online resources on other languages. } \\
\text { * Cultural appropriateness and literacy must also be considered. } \\
\text { * Larger studies need to be developed. } \\
\text { * Future studies need to employ more rigorous evaluation design with long-term follow-up } \\
\text { periods. } \\
\text { * Call for more studies that design online cancer support tailored to different disease }\end{array}$ \\
\hline
\end{tabular}




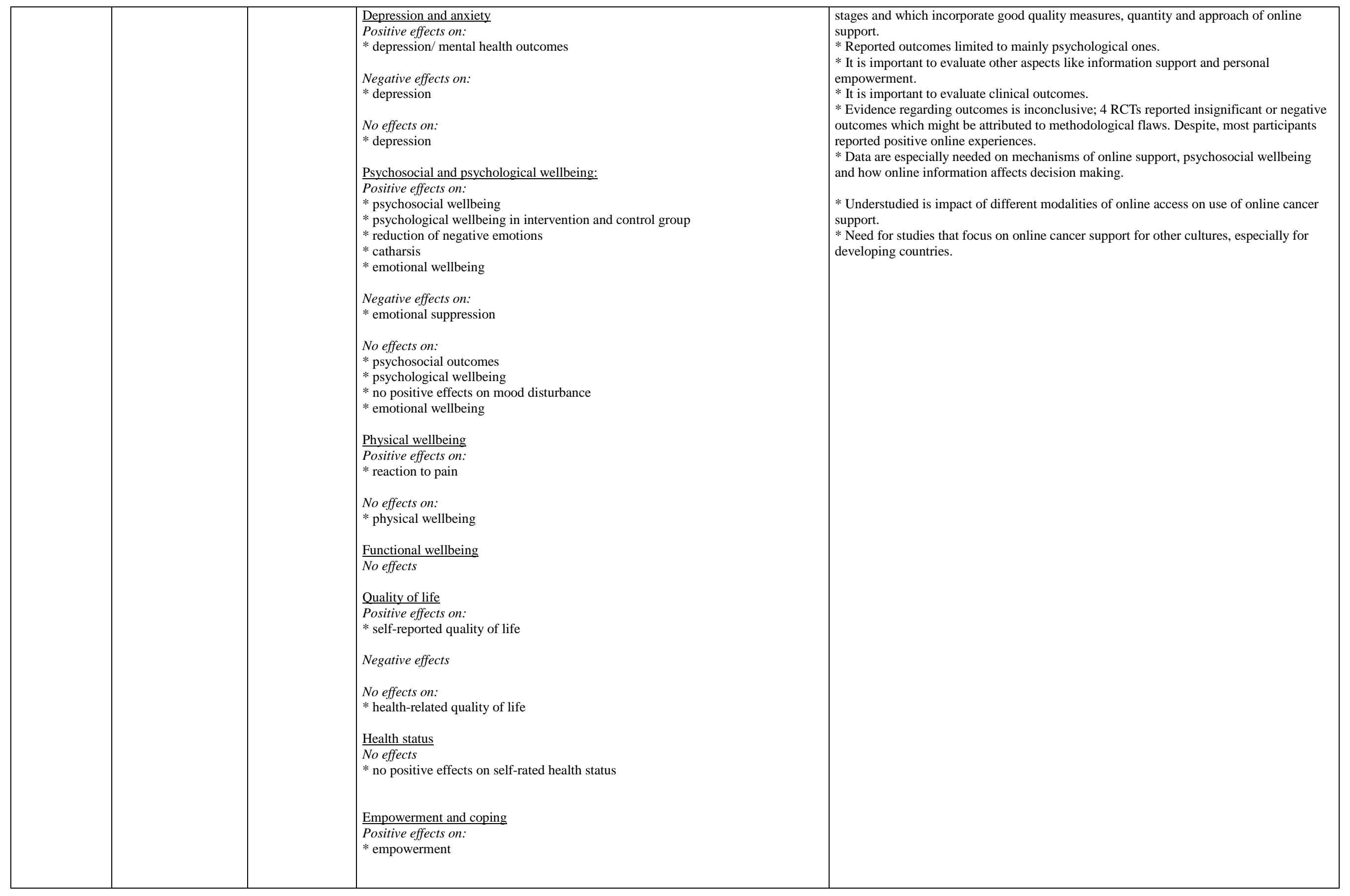




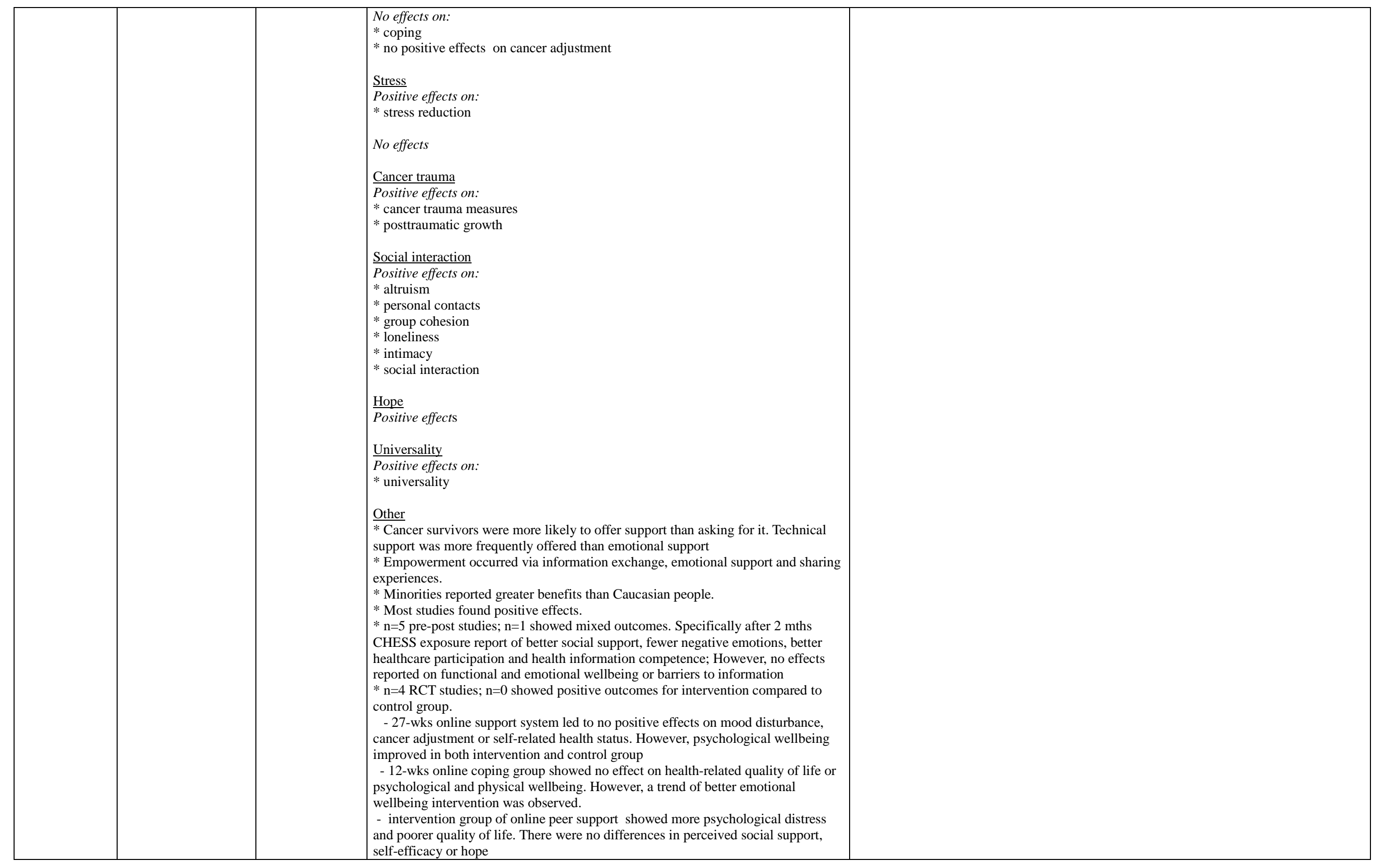




\begin{tabular}{|c|c|c|c|c|}
\hline $\begin{array}{l}\text { Johansen et al. } \\
2012[19] \\
3,5\end{array}$ & $\begin{array}{l}\text { Various: } \\
\text { *Equal to } \\
\text { duration/frequency of } \\
\text { intervention. } \\
\text { * } 2 \text { visits (before } \\
\text { treatment, } 4-6 \text { wks } \\
\text { later) } \\
\text { * Before visit, } 4 \text { times } \\
\text { * } 1 \text { consultation } \\
\text { * Up to } 1 \text { yr (once per } \\
\text { encounter during } \\
\text { treatment, once week } \\
\text { during hospital stay, } \\
\text { once outpatient visit } \\
\text { in up to } 4 \text { visits) } \\
\text { * Approx. } 6 \text { mths } \\
\text { * } 4 \text { cycles } \\
\text { chemotherapy (12-16 } \\
\text { wks) }\end{array}$ & $\begin{array}{l}\text { All potentially } \\
\text { relevant } \\
\text { outcomes }\end{array}$ & $\begin{array}{l}\text { Support } \\
\text { Positive effects on: } \\
\text { * reduction on perceived needs. However, no difference between intervention group } \\
\text { and control group. } \\
\text { Depression and anxiety } \\
\text { Positive effects on: } \\
\text { * reductions of anxiety levels and depression. However, no difference between } \\
\text { intervention group and control group. } \\
\text { Psychological wellbeing } \\
\text { Positive effects on: } \\
\text { * positive effect on emotional well-being was associated with data feedback } \\
\text { No effects on: } \\
\text { * no association between better emotional wellbeing and instrument completion } \\
\text { Quality of life } \\
\text { Positive effects on: } \\
\text { * clinically meaningful improvement and better of health related quality of life. } \\
\text { However, no difference between intervention group and control group } \\
\text { * association between improvement of health related quality of life and explicit use } \\
\text { of health related quality of life data, discussion of pain and role function } \\
\text { Symptoms } \\
\text { Positive effects on: } \\
\text { * decrease in symptom distress, over time } \\
\text { * decrease in need for symptom management support, over time } \\
\text { * patients who reported debilitating physical symptoms at visit } 2 \text { are less likely to } \\
\text { report debilitating physical symptom visit } 3 \text {. }\end{array}$ & $\begin{array}{l}\text { Conclusion } \\
\text { * So far, research focused on five specific patient groups, among which cancer patients. } \\
\text { * The evidence can be structured into four health service innovation categories: } \\
\text { consultation support, monitoring with clinician support, self-management with clinician } \\
\text { support, and therapy. Most of the research has been conducted within four combinations, } \\
\text { among which consultation support innovation in the cancer patient group. } \\
\text { Reflections } \\
\text { * Cancer patients who receive chemotherapy or radiation therapy (or both) for a period } \\
\text { from } 6 \text { months to a year could theoretically benefit from both monitoring and self- } \\
\text { management approaches. Yet, electronic symptom reporting for this group of patients has } \\
\text { mostly been studied in the context of consultation support. }\end{array}$ \\
\hline $\begin{array}{l}\text { Ryhanen et al. } \\
2010[20] \\
3,5\end{array}$ & $\begin{array}{l}\text { Various: } \\
\text { * Pre-education, post- } \\
\text { education, post-visit } \\
\text { * Pre-intervention, } \\
\text { post-intervention, } \\
\text { post-counselling tests, } \\
\quad 6 \text { mths } \\
\quad \text { follow-up } \\
\text { * Pre-test, post-test, } 9 \\
\text { mths follow-up } \\
\text { * Pre-operative, pre- } \\
\text { surgery, post-surgery } \\
\text { * Pre-test, } 2 \text { mths, } 5 \\
\text { mths follow-up } \\
\text { * Pre-test, } 12 \text { wks } \\
\quad \text { follow-up } \\
\text { * Pre-test, post-test } 4 \\
\text { mths after } \\
\text { * Pre-test and post- } \\
\text { test measures, not } \\
\text { specified } \\
\text { * One measure } \\
\text { * Duration of trials: } \\
\text { Not specifically } \\
\end{array}$ & $\begin{array}{l}\text { All potentially } \\
\text { relevant } \\
\text { outcomes }\end{array}$ & $\begin{array}{l}\text { Knowledge and information } \\
\text { Positive effects on: } \\
\text { * increase in knowledge level about breast cancer } \\
\text { * increase in knowledge level due to interactive method } \\
\text { * perceived information competence } \\
\text { * information competence for those who spent more time in the interactive series } \\
\text { Support } \\
\text { Positive effects on: } \\
\text { * increase in social support } \\
\text { Decision making } \\
\text { *ositive effects on: } \\
\text { * content of information helped patients to make decisions } \\
\text { Healthcare participation and patient involvement } \\
\text { Positive effects on: } \\
\text { * healthcare participation } \\
\text { * content of information influenced behavioral in taking care of breast health and } \\
\text { participate in healthcare }\end{array}$ & $\begin{array}{l}\text { Conclusion } \\
\text { Results suggest: } \\
\text { * Positive relationship between Internet or interactive computer-based patient education } \\
\text { program use and knowledge levels of breast cancer patients. This also has a positive effect } \\
\text { patient satisfaction. } \\
\text { * Use of Internet and interactive computer programs are associated with better health } \\
\text { information competence. However, use of Internet or interactive computer programs did } \\
\text { not independently contribute to enhanced learning outcomes. } \\
\text { * Education method: a) did not affect patient involvement although, b) patients tend to } \\
\text { learn more about breast cancer treatment after using multimedia program than after } \\
\text { reading a brochure and c) greater proportion of women in intervention group reported they } \\
\text { had assumed a significantly more passive role than originally preferred after using } \\
\text { interactive computer program. } \\
\text { * Internet can be used to raise knowledge level although results do not show expected } \\
\text { outcomes on patients' behavior. } \\
\text { * There is a need to develop and to research Internet-based patient education. } \\
\\
\text { Reflections } \\
\text { * No clear effect of Internet or interactive computer-based patient education on care of } \\
\text { breast cancer patients identified, because effects differed across studies. } \\
\text { * Most results were not statistically significant except for knowledge-related issues and } \\
\text { some single outcomes. } \\
\text { * Different instruments were used. Most of them were specifically designed for the study, } \\
\text { which makes it difficult to compare outcomes. }\end{array}$ \\
\hline
\end{tabular}




\begin{tabular}{|c|c|c|c|c|}
\hline & reported. & & $\begin{array}{l}\text { Depression and anxiety } \\
\text { No effects on: } \\
\text { * depression } \\
\text { * anxiety. Anxiety level was higher after face-to-face counselling } \\
\text { Social interaction } \\
\text { Positive effect on: } \\
\text { * decrease in loneliness } \\
\text { Other } \\
\text { * The most common outcome measures were issues related to knowledge and } \\
\text { satisfaction-related issues } \\
\text { * Issues pertaining to decision-making and quality of life were also measured. } \\
\text { * Some other issues like social support, coping, stress, loneliness, depression and } \\
\text { anxiety were tested. }\end{array}$ & $\begin{array}{l}\text { * Some outcome issues were measured in only one study. } \\
\text { * Outcomes measures varied widely which makes it difficult to establish effects of patient } \\
\text { education with Internet } \\
\text { or interactive computer. } \\
\text { * Internet or interactive computer-based patient educational programs for breast cancer } \\
\text { patients care are effective in increasing patients' knowledge about breast cancer and useful } \\
\text { in decision-making regarding participation in care } \\
\text { * The methodological quality of the studies varied widely and in some studies was quite } \\
\text { poor. }\end{array}$ \\
\hline $\begin{array}{l}\text { Salonen et al. } \\
2014 \text { [21] } \\
3,5\end{array}$ & $\begin{array}{l}\text { Various: } \\
\text { * Time diagnosis, } 4 \\
\text { mths } \\
\text { * Enrolment, } 1 \text {-2 wks } \\
\text { post-intervention, } 3 \\
\text { mths later } \\
\text { * Pre-post } \\
\text { * In some instances, } \\
\text { time measurement } \\
\text { was not reported }\end{array}$ & $\begin{array}{l}\text { All potentially } \\
\text { relevant } \\
\text { outcomes }\end{array}$ & $\begin{array}{l}\text { Knowledge and information } \\
\text { Positive effects on: } \\
\text { * increase in ability to understand treatment options } \\
\text { * better preparation for discussion of treatment options } \\
\text { * promotion of knowledge gains } \\
\text { Support } \\
\text { Positive effects on: } \\
\text { * improved satisfaction with cancer information for men } \\
\text { * marginal improvement of perceived oncologist informational support for men } \\
\text { Decision making } \\
\text { Positive effects on: } \\
\text { * increase in levels of decision control after treatment decision in both intervention } \\
\text { and control group } \\
\text { * reduction of levels of decision conflict after treatment decision in both } \\
\text { intervention and control group } \\
\text { * increase in patient involvement in decision making } \\
\text { Negative effects on: } \\
\text { * decrease in partner involvement in decision making } \\
\text { Depression and anxiety } \\
\text { Positive effects on: } \\
\text { * reduction of depression symptoms } \\
\text { Psychological wellbeing } \\
\text { Positive effects on: } \\
\text { * reduction of psychological distress for patients and partners, at } 4 \text { mths } \\
\text { * reduction of (psychological) distress } \\
\text { Quality of life } \\
\text { Positive effects on: } \\
\text { * increase in long-term quality of life related to sexual functioning and cancer } \\
\text { worry. No difference between intervention and control group } \\
\text { * prevention of deterioration of functional quality of life and mental quality of life } \\
\text { Empowerment and coping } \\
\text { Positive effects on: } \\
\text { * patients were more empowered to discuss their disease which led to ability to } \\
\text { control and deal with disease }\end{array}$ & $\begin{array}{l}\text { Conclusion } \\
\text { * This review supports conclusion that computer or Internet-based patient education can } \\
\text { improve patients' knowledge, self-efficacy and provide emotional and spiritual support. } \\
\text { This conclusion is consistent with other systematic reviews. } \\
\text { * Social integration and knowledge sharing occurring through these new technologies } \\
\text { possibly increase understanding of disease, treatment options and side effects. } \\
\text { * Development on computer and Internet-based programs for prostate cancer patients is } \\
\text { still ongoing. } \\
\text { * The need to provide more informed and interactive information resources aimed at } \\
\text { patients for patient } \\
\text { education purposes has underlined benefits of using computer technology to support and } \\
\text { improve patients' knowledge during learning process. } \\
\text { Reflections } \\
\text { * Difficult to compare interventions and their impact, because of dissimilarity of } \\
\text { multimedia and single media intervention. } \\
\text { * Therefore, no conclusions can be made or any specific advice given for future regarding } \\
\text { technology or outcome quality. } \\
\text { * The review limitations were based on relatively small number of included articles and } \\
\text { included studies contained various methodological weaknesses. This urges for caution in } \\
\text { drawing firm conclusions. }\end{array}$ \\
\hline
\end{tabular}




\begin{tabular}{|c|c|c|c|c|}
\hline $\begin{array}{l}\text { Ventura et al., } \\
2013 \text { [22] } \\
3\end{array}$ & $\begin{array}{l}\text { All studies } \\
\text { longitudinal: } \\
\text { - Before-after design } \\
\text { - Until } 12 \text { mths after } \\
\text { inclusion }\end{array}$ & $\begin{array}{l}\text { All potentially } \\
\text { relevant } \\
\text { outcomes }\end{array}$ & $\begin{array}{l}\text { Support } \\
\text { Positive effects on: } \\
\text { * increase in social support } \\
\text { * use of interactive services alone likely improves social support } \\
\text { No effects on: } \\
\text { * social support } \\
\text { Decision making } \\
\text { Positive effects on: } \\
\text { * increase in decision making variables } \\
\text { Healthcare participation and patient involvement } \\
\text { Positive effects on: } \\
\text { * increase in healthcare participation } \\
\text { * association between Caucasian people with early -stage breast cancer and } \\
\text { increased healthcare participation } \\
\text { No effects on: } \\
\text { * healthcare participation } \\
\text { Quality of life } \\
\text { Positive effects } \\
\text { No effects } \\
\text { Health status } \\
\text { Positive effects on: } \\
\text { * increase in general health } \\
\text { No effects } \\
\text { Health competence and health literacy } \\
\text { Positive effects on: } \\
\text { * increase in health competence } \\
\text { * use of both information and interactive services likely leads to improvements in } \\
\text { health competence } \\
\text { * increase in health literacy } \\
\text { No effects on: } \\
\text { * health literacy } \\
\text { * health competence } \\
\text { Empowerall satisfaction } \\
\text { Positive effects on: } \\
\text { * increase in self-care ability } \\
\text { * improvement in coping } \\
\text { No effects on: } \\
\text { * coping } \\
\text { Oofts }\end{array}$ & $\begin{array}{l}\text { Conclusion: } \\
\text { * eHealth interventions that allow informational and supportive needs being satisfied are } \\
\text { being designed and implemented and are likely to have positive effects on number of } \\
\text { outcomes for individuals with different preferences and priorities. } \\
\text { * Even though several communalities could be found in the reviewed interventions, } \\
\text { methodological aspects of the design, implementation and evaluation remain unclear. } \\
\text { Models and applied theories are needed to clarify such issues, thus enhancing the } \\
\text { credibility and applicability of supportive eHealth interventions across target populations. } \\
\text { Reflections } \\
\text { * Despite similar purposes, interventions analyzed seem to lack common structure linking } \\
\text { all aspects of a supportive eHealth program. Lacking such a structure, interventions are } \\
\text { difficult to adapt across cultures or cancer patient groups and are barely replicable. } \\
\text { * Internet interventions seem to produce favorable change behavior and positive } \\
\text { outcomes, although process of achieving them remains unclear. } \\
\text { * Overall satisfaction and quality of life are considered being multidimensional variables } \\
\text { affected by several factors. These variables thus can hardly be seen as a direct result of } \\
\text { supportive eHealth interventions, but more as an ultimate outcome. } \\
\text { * Most researchers developed own measurement instruments which might lead to } \\
\text { erroneous interpretations of results when comparing several effectiveness reports. } \\
\text { Different instruments do not allow comparison across outcomes. } \\
\text { * Majority of studies focus on women with breast cancer. Although some studies focus on } \\
\text { prostate cancer, gender comparisons regarding intervention use and outcomes are not } \\
\text { provided. }\end{array}$ \\
\hline
\end{tabular}


* Most commonly measured outcomes: health literacy, incl. various aspects disease,

treatment, side-effects knowledge, healthcare services and/or self-care

* Selective use eHealth interventions more likely to predict benefits than total time

spent using intervention 
